I N T ER N ATIONAL MONETARY FUND

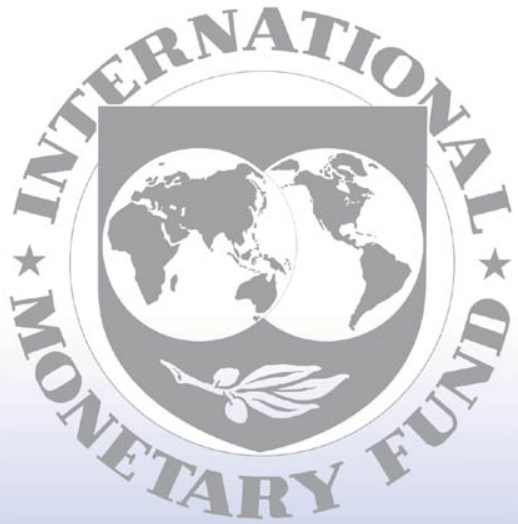

Staff

Country

Reports 


\section{Algeria: 2003 Article IV Consultation-Staff Report; Staff Statement; Public Information Notice on the Executive Board Discussion; and Statement by the Executive Director for Algeria}

Under Article IV of the IMF's Articles of Agreement, the IMF holds bilateral discussions with members, usually every year. In the context of the 2003 Article IV consultation with Algeria, the following documents have been released and are included in this package:

- the staff report for the 2003 Article IV consultation, prepared by a staff team of the IMF, following discussions that ended on October 13, 2003, with the officials of Algeria on economic developments and policies. Based on information available at the time of these discussions, the staff report was completed on December 16, 2003. The views expressed in the staff report are those of the staff team and do not necessarily reflect the views of the Executive Board of the IMF.

- a staff statement of January 14, 2004 updating information on recent developments.

- a Public Information Notice (PIN) summarizing the views of the Executive Board as expressed during its January 14, 2004 discussion of the staff report that concluded the Article IV consultation.

- a statement by the Executive Director for Algeria.

The document(s) listed below have been or will be separately released

Selected Issues Paper and Statistical Appendix

The policy of publication of staff reports and other documents allows for the deletion of market-sensitive information.

To assist the IMF in evaluating the publication policy, reader comments are invited and may be sent by e-mail to publicationpolicr@imf.org.

Copies of this report are available to the public from

International Monetary Fund - Publication Services

$70019^{\text {th }}$ Street, N.W. $\bullet$ Washington, D.C. 20431

Telephone: (202) 623-7430 - Telefax: (202) 623-7201

E-mail: publications@imf.org • Internet: http://www.imf.org

Price: $\$ 15.00$ a copy

International Monetary Fund

Washington, D.C. 
INTERNATIONAL MONETARY FUND

\author{
ALGERIA \\ Staff Report for the 2003 Article IV Consultation \\ Prepared by the Staff Representatives for the \\ 2003 Consultation with Algeria \\ (In consultation with other departments) \\ Approved by Lorenzo L. Perez and Matthew Fisher
}

December 16, 2003

- Discussions for the 2003 Article IV consultation were held in Algiers during October 1-13, 2003. The staff team comprised Messrs. Lazare (head), Callier, Flörkemeier, Ms. Koranchelian, (all MCD), and Mr. Bouscharain (MFD). Mr. Durand (MFD) participated in the policy discussions. Messrs. Kirilenko and Soueid (both ICM) also visited Algiers to advise the authorities on external debt management. Mr. Maherzi, Assistant to the Executive Director for Algeria, participated in the discussions.

- The mission met with the governor of the Bank of Algeria, the Minister of Finance, the Delegate Ministers for Financial Reform and for Participation and Promotion of Investment, the economic advisor to President Bouteflika, and other senior officials. The mission also met with representatives from an employers' association, banks, and nonfinancial corporations, including the state-owned hydrocarbon company Sonatrach.

- At the conclusion of the 2002 Article IV consultation on February 24, 2003, Directors commended the authorities for preserving macroeconomic stability and making progress in a number of reforms. They cautioned that fiscal stimulus cannot substitute for the reforms needed to achieve a lasting improvement in growth and employment. They encouraged the authorities to take additional steps towards establishing a sound banking system.

- Presidential elections are scheduled for April 2004. President Bouteflika is expected to seek a second term. Mr. Benflis, current leader of the main party in the national assembly and former prime minister (replaced by Mr. Ouyahia in May 2003), has declared his candidacy. The security situation has further improved in 2003, but sporadic incidents of violence have persisted in a few regions.

- Persistent data weaknesses exist, especially in government finance statistics and price indices (Appendix III). They hamper the monitoring of economic conditions and the formulation of policies.

- Algeria accepted the obligations under Article VW in September 1997 and tnaintains an exchange system free of restrictions on payments and transfers for current international transactions.

- The authors of the report are Messrs. Lazare, Calier, Flörkemeier, and Ms. Koranchelian. 
Contents

Executive Summary.

I. Background 5

II. Recent Economic Developments and Prospects for 2003

III. Outlook.

A. 2004 Outlook

B. Medium-Term Policies

IV. Policy Discussions

A. Overview.

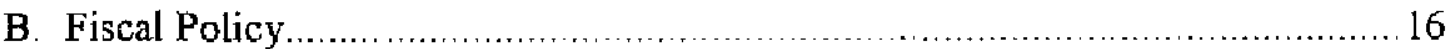

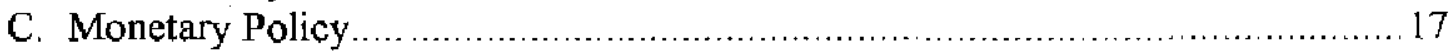

D. External Policies $\ldots \ldots \ldots \ldots \ldots \ldots \ldots \ldots \ldots \ldots \ldots \ldots \ldots \ldots \ldots \ldots \ldots \ldots \ldots \ldots \ldots \ldots \ldots \ldots 18$

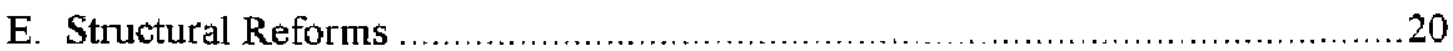

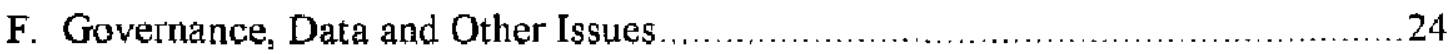

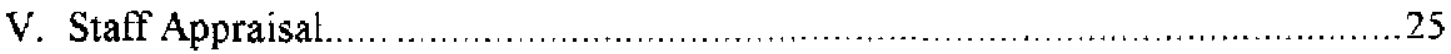

Tables

1. Selected Economic and Financial Indicators, 1999-2004

2. Summary of Central Government Operations, 1999-2004 _.........................28

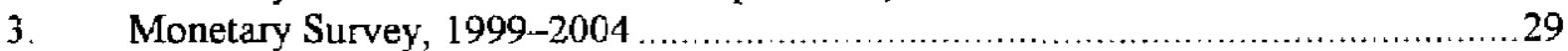

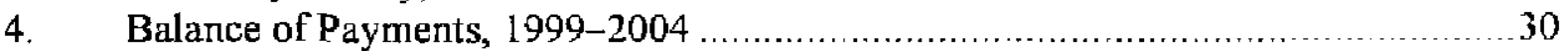

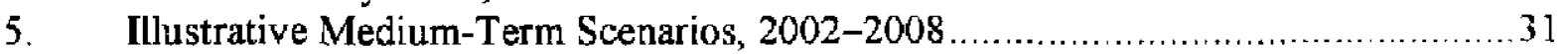

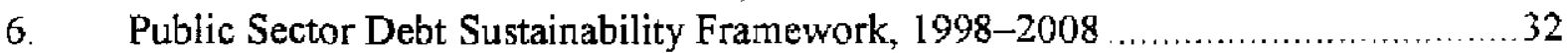

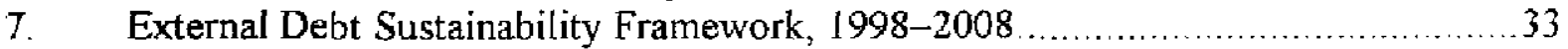

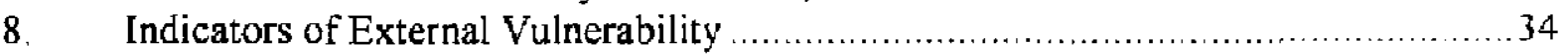

\section{Charts}

\begin{tabular}{|c|c|}
\hline & Real GDP Growth. \\
\hline 2. & 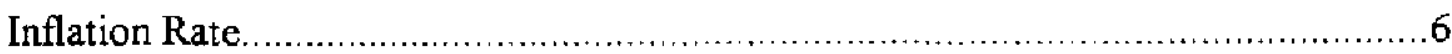 \\
\hline 3. & Capital Expenditure. \\
\hline 4. & 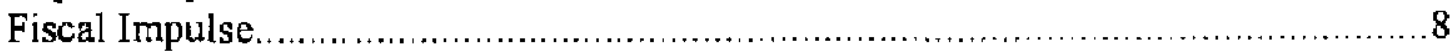 \\
\hline 5. & 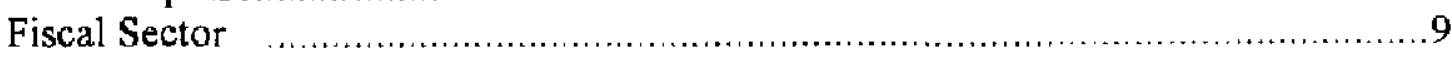 \\
\hline 6. & 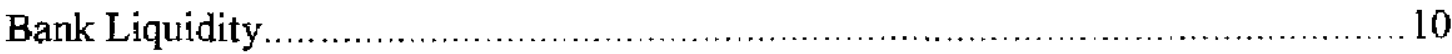 \\
\hline 7. & 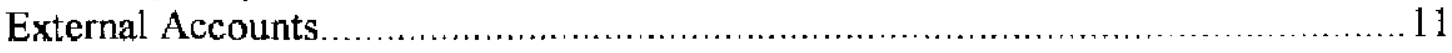 \\
\hline 8. & Real and Nominal Exchange Rates \\
\hline
\end{tabular}


Boxes

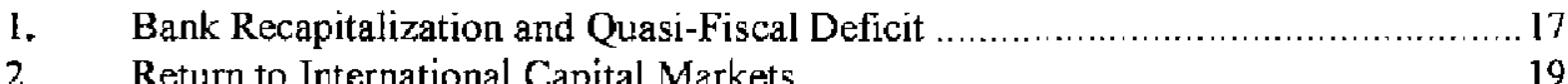

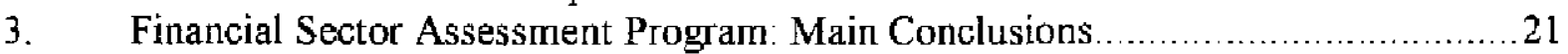

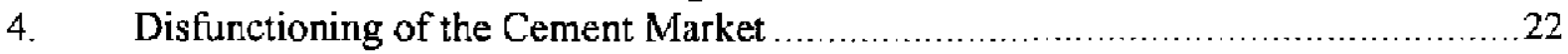

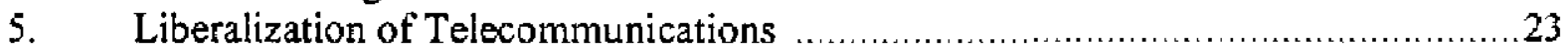

Appendices

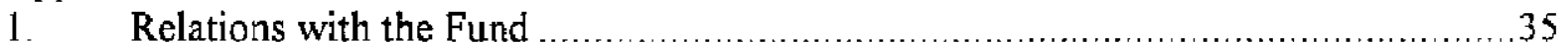

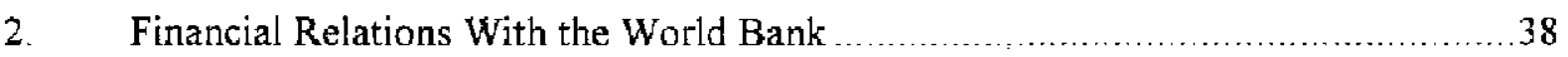

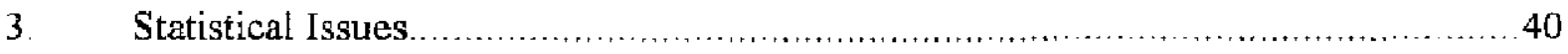

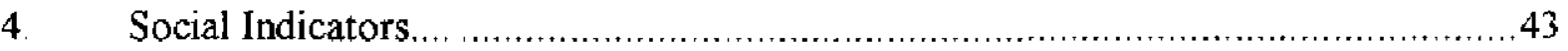




\section{EXECUTIVE SUMMARY}

\section{Recent developments}

- Underpinned by the relaxation of the fiscal stance prevailing since 2001 and boosted by a strong performance in the agricultural and hydrocarbon sectors, real growth has picked up since 2002 . The strong bydrocarbon export performance has allowed Algeria to strengthen its external position and record a budget surplus.

- The procyclical fiscal policy has heightened the vulnerability of public finances to swings in oil prices It has also fueled money and credit growth. Owing to electoral considerations and the reconstruction needs following the May 21 earthquake, the fiscal stimulus is expected to be maintained until at least mid-2004.

- In the second semester of 2003 , the authorities intervened to correct the real effective depreciation of the dinar that had resulted, earlier in the year, from the rise in the euro.

- Despite major achievements in trade liberalization, the drive for structural reforms has slowed down since mid-200L. Forthcoming presidential elections and the fraudulent bankruptcy of the two largest (yet small) private banks in 2003 are further limiting the appetite for reforms.

\section{Policy discussions}

- Policy discussions focused on the macroeconomic risks that could arise from the continuation of current policies and on longer-term challenges to achieve sustainable growth. The authorities reiterated the need to maintain public expenditure at a high level over the next few years to face reconstruction and social needs and to support growth in the absence of a marked pickup in private activity.

- While acknowledging Algeria's existing reconsticuction and social needs, staff underscored the necessity to maintain fiscal discipline over the medium term and stressed that fiscal expansion was no substitute for growth-enhancing structural reforms that would foster private activity. Staff emphasized that fiscal policy had become procyclical and stressed that the fiscal position's vulnerability ta oil price swings could undermine macroeconomic stability. It also pointed out that sizable quasi-fiscal expenditures intermediated by public banks implied that the financial position of the government was weaker than suggested by official data. Staff suggested stabilizing public expenditures as a percentage of nonhydrocarbon GDP, at a level consistent with medium-term fiscal constraints.

- The strong expansion of credit to the economy since late 2002 constitutes a threat to macroeconomic stability and possibly to bank soundness. Staff recommended tightening monetary policy through full absorption of excess bank liquidity. Staff cautioned against targeting a further appreciation of the dinar exchange rate, given the adverse impact of such policy on private activity, employment, and the fiscal position.

- Staff underlined that comprehensive structural and institutional reform is a prerequisite for shifting the Algerian economy to a higher and sustainable growth path and reducing unemployment and poverty. The priorities are: reforming the banking sector, privatizing/restructuring nonfinancial public enterprises, establishing an effective real estate market, increasing employment elasticity to growth and improving public services, transparency, and governance.

- The authorities were satisfied with the FSAP conclusions and agreed with staff on a number of technical assistance missions to implement the FSAP recommendations. ICM advised the authorities to repay by anticipation a portion of the external public debt and request a rating of Algeria's sovereign risk. 


\section{BACKGROUND}

1. Algeria restored macroeconomic stability in the context of Fund supported programs (1994-98), after several years of stop-and-go policies, political and social tensions, volatile oil markets, and balance of payments crises. However, unemployment and poverty continued to rise.

2. After a few years of tight fiscal policies, increased political pressures in a context of buoyant oil revenues have led the authorities to follow since 2001 an expansionary fiscal stance aimed at boosting growth and employment. This policy has indeed succeeded in the short term and resulted in rising growth, as well as higher agricultural and residential housing investment, without affecting macroeconomic stability based on favorable oil prices.

3. The transition from a centrally planned to a market economy undertaken in the 1980s has not yet been completed. Despite early structural reform successes in the $1990 \mathrm{~s}$ (trade and exchange reforms, price liberalization), the business environment is still not conducive to strong, private sector-driven growth, because of a lengthy judicial procedure, infrastructure bottlenecks, ill-defined land and real estate property rights, and an inefficient payments system. ${ }^{1,2}$ Weak governance and security concerns are also weighing on investors' decisions. Public banks' financing of large loss-making public enterprises is hampering the financial system's capacity to mobilize and allocate resources efficiently. As a result of these weaknesses, unemployment remains high and the informal sector large. ${ }^{3}$

\section{Recent ECONomic DeVelopiments and Prospects for 2003}

\section{A. Activity and Inflation}

4. Economic activity improved in 2002-03. Underpinned by a large fiscal stimulus, high oil prices, and a sharp rise in oil output, real growth rebounded in 2002 and 2003 (Chart 1 and Table 1). Despite adverse weather conditions, output growth exceeded 4 percent in 2002. In 2003, a bumper crop has also boosted growth. As a result, the high unemployment rate (estimated at 25.9 percent of the labor force in 2002) is expected to have dropped somewhat.

\footnotetext{
'Nashashibi and alii (1998), Algeria: Stabilization and Transition to the Market, Occasional Paper 165.

${ }^{2}$ World Bank (November 2003), Aigeria Investment Climate Assessment. The 2003-04 Competitiveness Report of the World Economic Forum ranks Algeria in the bottom 15 percent of all surveyed countries for business competitiveness and in the bottom 30 percent for growth competitiveness, well below the Maghreb average.

${ }^{3}$ The 2003 UNDP Human Development Report ranks Algeria $107^{\text {th }}$ out of 175 countries.
} 


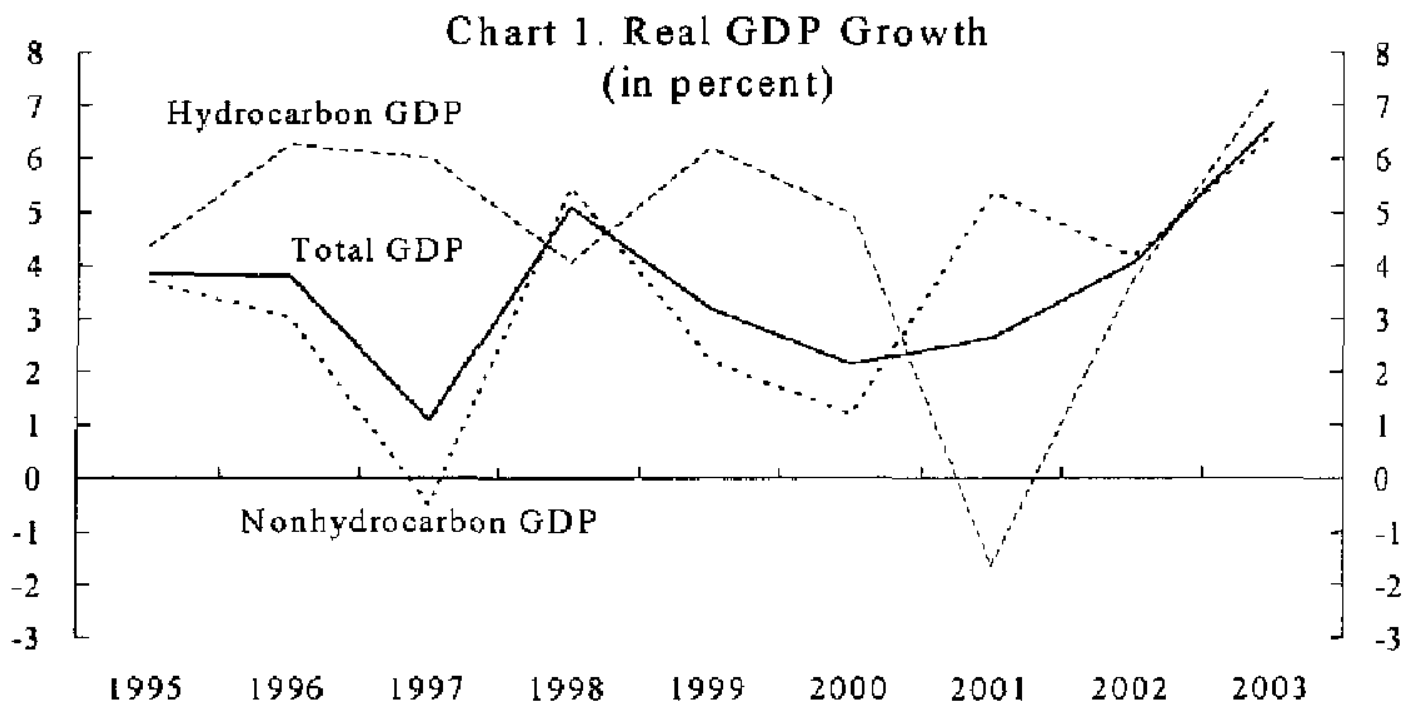

5. Inflation receded in $\mathbf{2 0 0 2}$ and is likely to remain low in $\mathbf{2 0 0 3}$ (Chart 2). Food prices and the gradual reduction in the external tariff have kept inflation low despite abundant liquidity and booming credit.

Chart 2. Enflation Rate

(in percent)

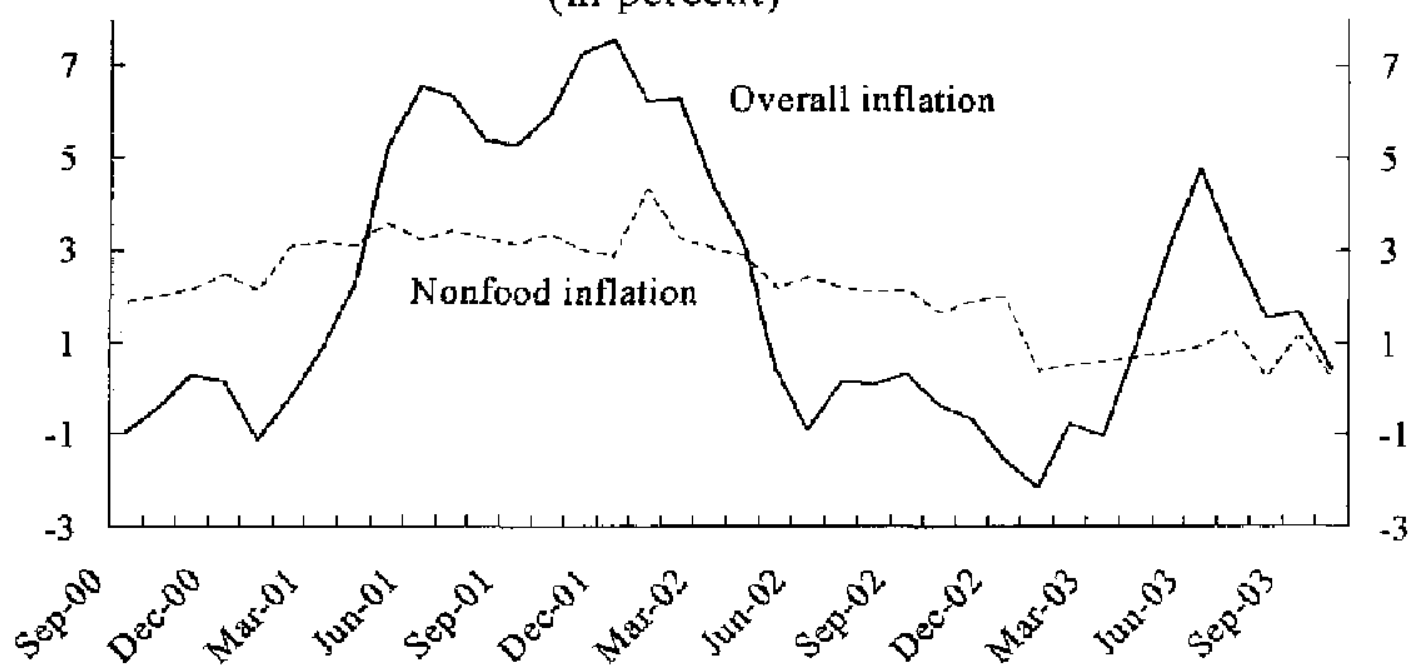




\section{B. Fiscal Policy}

6. In spite of a continued surge in expenditures, the overall fiscal balance is

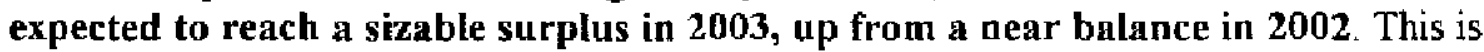
mainly the result of high hydrocarbon revenues, which are projected to increase by almost 4 percentage points of GDP compared to 2002. Expenditure growth-already strong in the 2003 initial budget - has been reinvigorated by reconstruction needs arising from the May 2003 earthquake. ${ }^{4}$ Capital expenditures, in particular, are projected to further increase to 18 percent of nonhydrocarbon GDP (NHGDP) in 2003 (Chart 3). Therefore, the already substantial nonhydrocarbon primary budget deficit - the main fiscal stance indicator-will increase sharply (Charts 4 and 5 , and Table 2).

\section{Chart 3. Capital Expenditure}
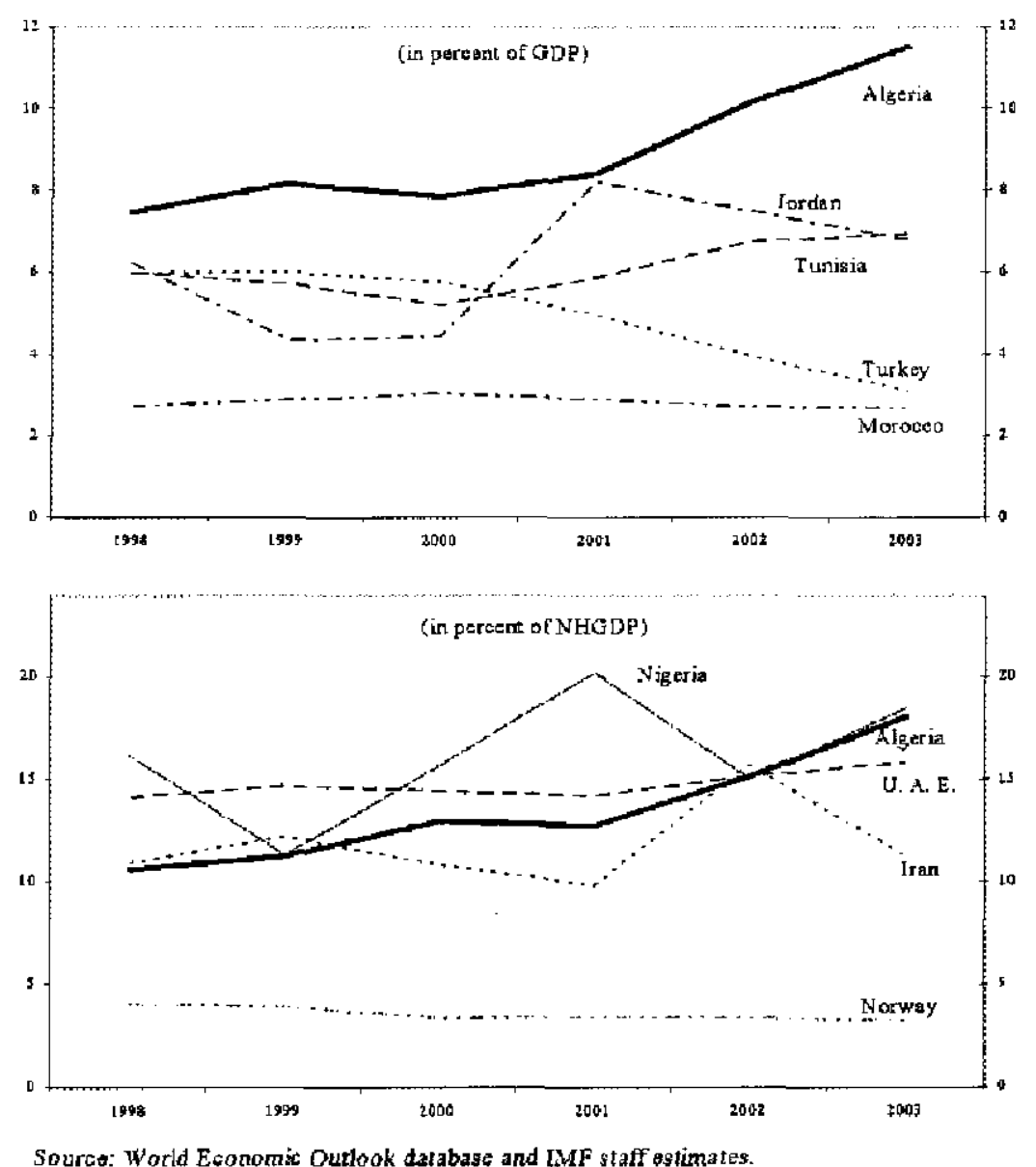

Source: World Economic Outlook talabase and IMF staff gstimates.

\footnotetext{
${ }^{4}$ In reaction to the earthquake, a supplementary budget law was adopted, providing for additional expenditures of DA 100 billion (about 2.5 percent of GDP).
} 


\section{Chart 4. Fiscal Impulse}

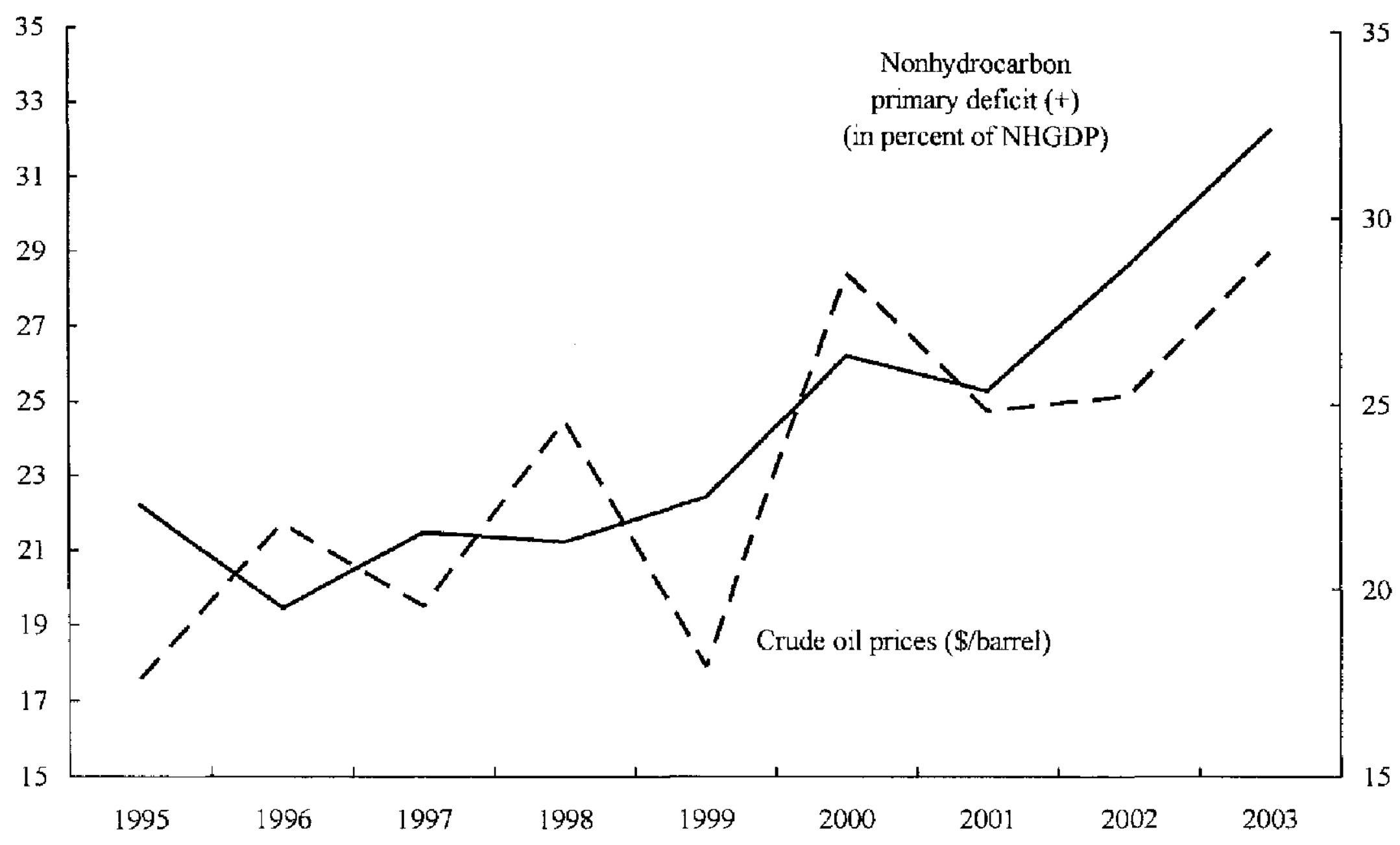


Chart 5. Algeria: Fiscal Sector

The overall fiscal balance improved in $2003 \ldots$

.. reflecting higher hydracarbon revenues...

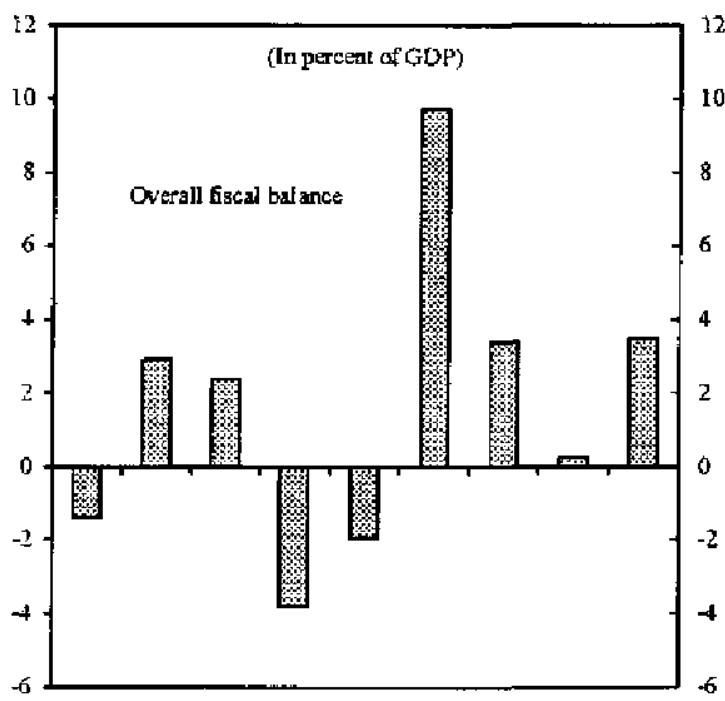

$\begin{array}{lllllll}1995 & 1996 \quad 1997 \quad 1998 & 1999 & 2000 & 2001 & 2002 \quad 2003\end{array}$

...and tax revenues...
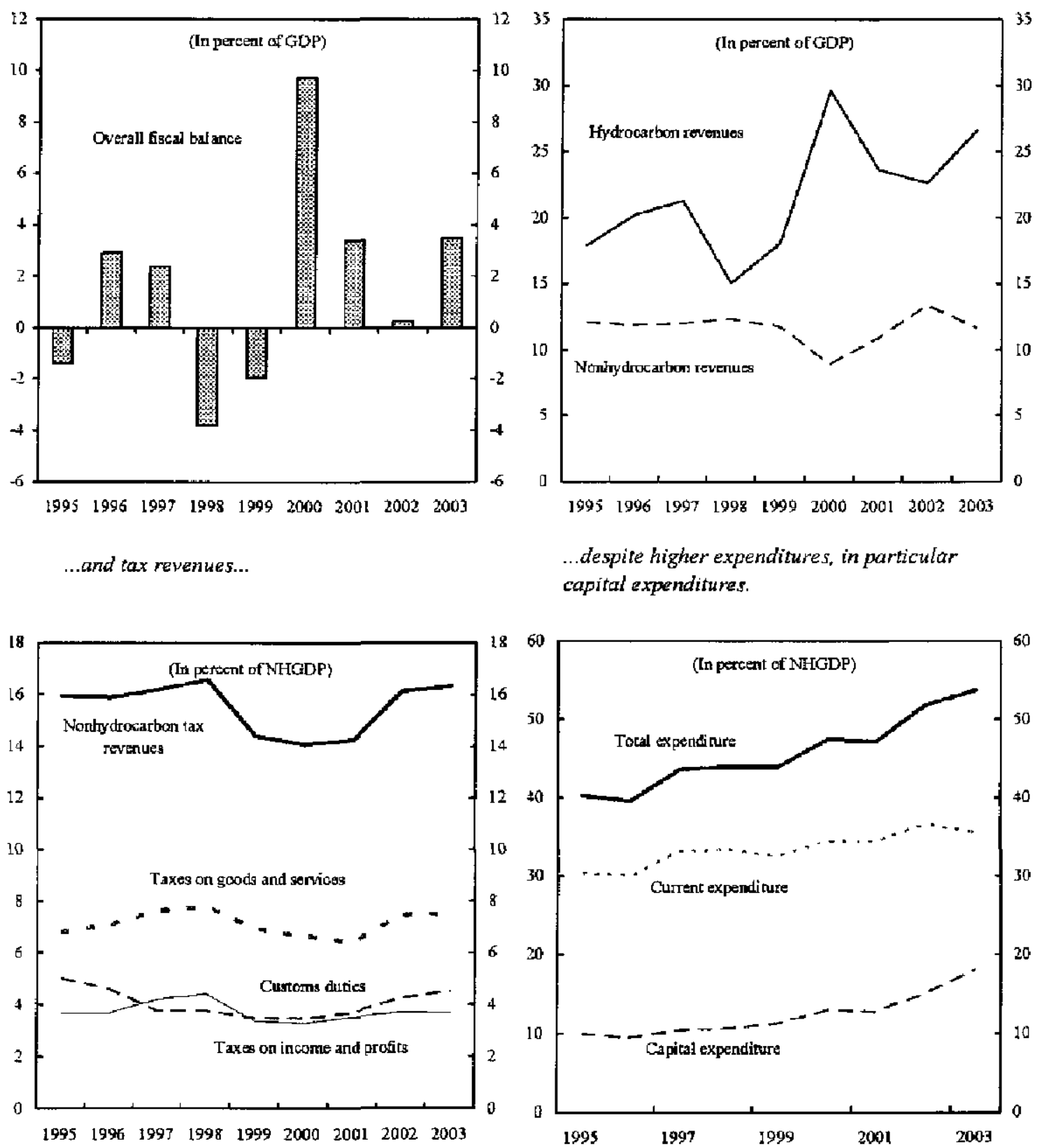

Sources: Algerian authorities and IMF staff estimates. 


\section{Monetary and Financial Sector Developments}

7. Since 2002, monetary policy has been accommodating and credit to the economy booming. Despite a 2 percentage point increase in reserve requirements and a rise in the amounts of central bank deposit auctions, money supply M2 is expected to increase substantially in 2003. This increase reflects in part the largely unsterilized surge in net foreign assets. ${ }^{5}$ Furthermore, credit to the economy accelerated in 2002 and 2003 (Chart 6 and Table 3). ${ }^{6}$ New credit has been concentrated in the private sector, including agriculture and housing.

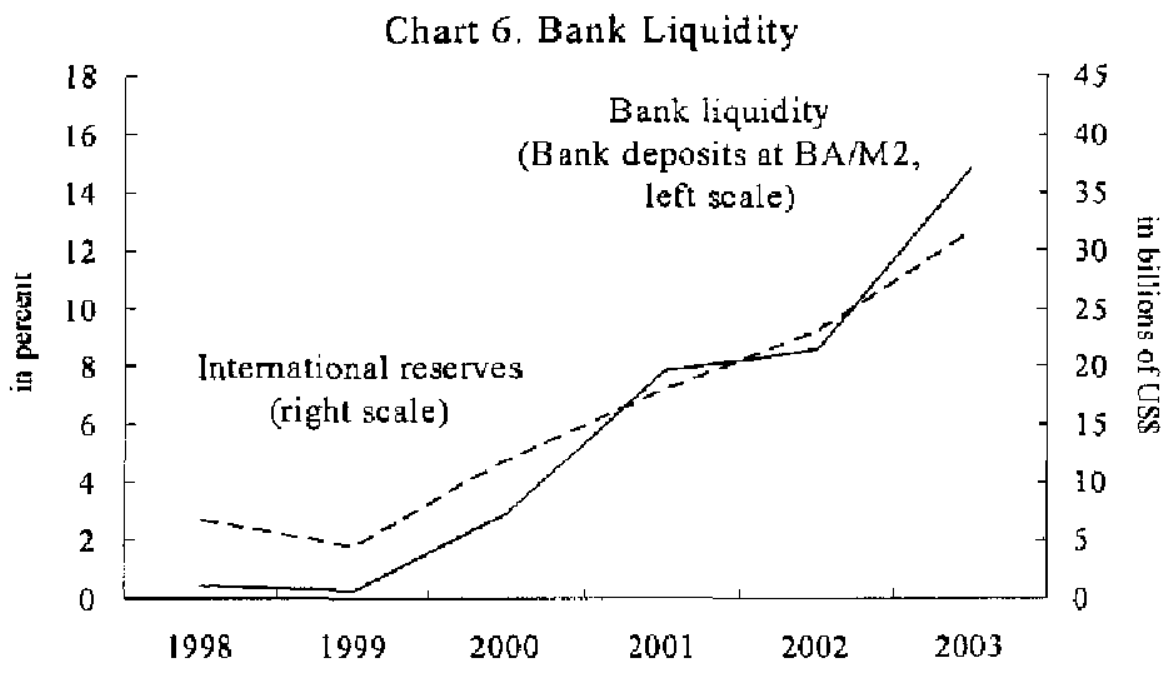

8. Two major developments took place in the banking sector. The two largest private banks (although small, with less than 6 percent of bank deposits) went bankrupt in 2003 because of fraudulent practices and violations of prudential regulations. Staff estimates that their liquidation will result in a one-off cost to the treasury as high as 2 percent of GDP (bailing out public entities which lost deposits). A new ordinance on money and credit addressing a variety of institutional issues highlighted by the private banks' failure was issued in August 2003.

\footnotetext{
'Depositing the government's share in hydrocarbon revenues on the treasury account at the Bank of Algeria (BA), instead of spending them, amounts to sterilization. Fiscal expansion, by spending this share, is tantamount to nonsterilization of a surge in net foreign assets.

${ }^{6}$ The projected flow of credit in 2003 exceeds the difference between the stocks of credit at end-2002 and end-2003, because of the impact of the liquidation of two private banks on monetary data.
} 


\section{External Developments}

9. Throughout 2002 and the first half of 2003 , the external position has continued to strengthen (Chart 7 and Table 4). Boosted by both higher prices and volumes, hydrocarbon exports surged in 2003 , leading to a sharp rise in the current account surplus and official reserves, which, at $\$ 30.4$ billion ( 22 months of imports) at end-October, exceed gross external debt.

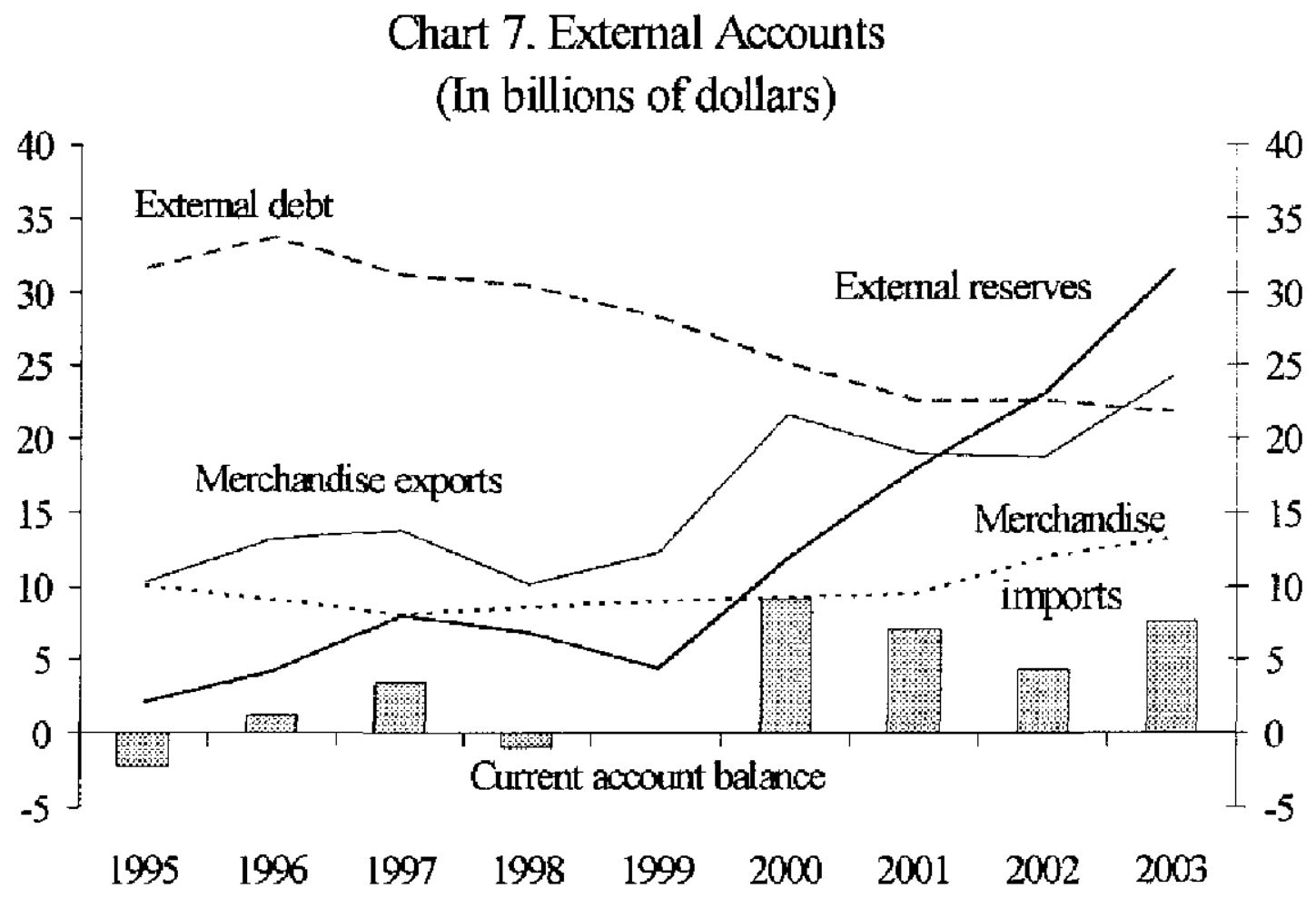

10. Following a depreciation in the first half of 2003 , the real effective exchange rate (REER) of the dinar has appreciated since July 2003 (Chart 8 ). The depreciation reflected the low inflation rate prevailing in Algeria together with the broad stability of the dinar relative to the dollar at a time when the euro appreciated. In the second half of 2003, upon evidence that the appreciation of the euro was more than a transitory event, BA intervened to correct the initial depreciation of the REER. By end November, the REER index was estimated to be in the vicinity of its end-2002 level. 
Chart 8. Real and Nominal Exchange Rates,

January 1994-September 2003

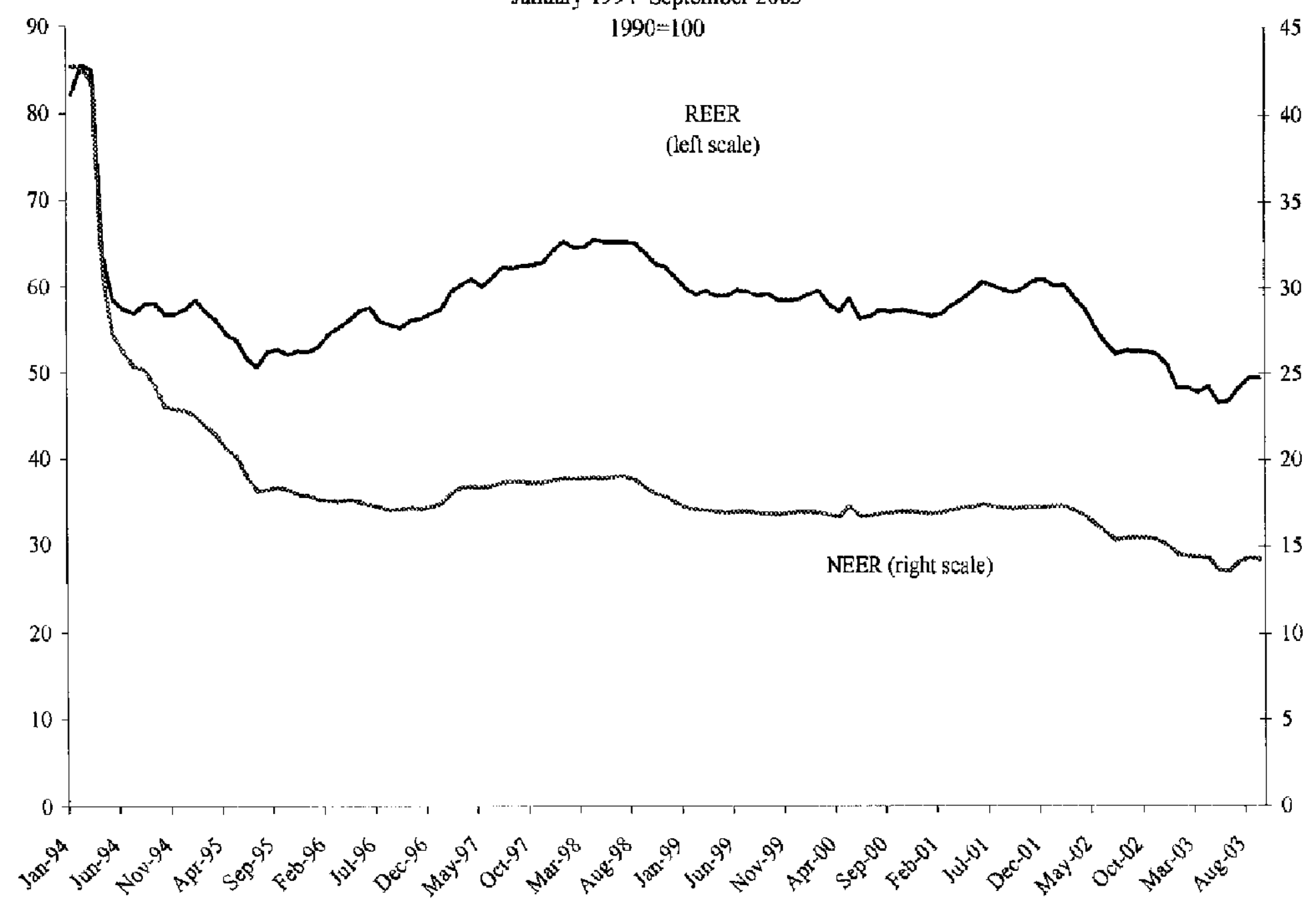




\section{E. Structural Reforms}

11. Despite a marked slowdown in the overall pace of reforms since 2001, progress has been achieved in two specific areas: trade liberalization and development of treasury securities markets. Regarding trade liberalization, the progressive elimination of the temporary surtax (which replaced the minimum dutiable values in 2001) continued in accordance with the pre-announced timetable. Furthermore, the legislative framework has been modernized to ensure consistency with World Trade Organization (WTO) rules, while negotiations towards Algeria's WTO accession are pursued actively. ${ }^{7}$ As for the development of securities markets, a systematic effort has been made to issue regularly tradable treasury securities covering a large spectrum of maturities to generate a reference yield curve. The Treasury has also initiated a program aimed at substituting standardized marketable securities in exchange for some of the bonds issued in the context of past bank restructurings.

\section{Furthermore, a pragmatic attitude towards privatization is being developed} though there have been few tangible results so far. Full or partial sales of state-owned enterprises to private investors, and transfers of assets to joint ventures with private investors are being prepared with a view to completing a few transactions by early 2004 . Nevertheless, attempts to privatize three cement factories, open up the capital of one state-owned bank, and transfer the management of Algiers' airport to the private sector did not come to fruition. ${ }^{8}$

\section{OUTLOOK AND RISKS}

\section{A. 2004 Outlook}

13. Overall, the outlook for 2004 seems favorable, although a return to normal weather conditions will result in lower growth in agriculture and thus in the overall economy, notwithstanding the continued fiscal expansion. Inflation is expected to increase slightly to about 4 percent, mainly owing to the impact of wage increases, the persistence of abundant bank liquidity, and a further expansion of credit to the economy. Despite the slight drop in hydrocarbon export prices, the current account balance is still projected to record a surplus, as nongovernment saving remains sufficient to offset the emerging fiscal deficit (see below). The external position will continue to strengthen. Nevertheless, fiscal expansion and pervasive quasi-fiscal expenditures keep building up medium-term vulnerabilities.

\footnotetext{
'New ordinances issued in 2003 cover (i) intemational trade; (ii) the organization of free trade zones; (iii) various aspects of the protection of intellectual property in trade transactions; and (iv) competition. A revision of the Code of Commerce is also under way.

${ }^{8}$ In 2003, only a brickyard was privatized. A multiple of reasons explain the failed privatizations, including the excessive constraints placed on potential buyers (cement), irregularities in the administrative decision selecting the government's funancial advisor (bank), and the inexperience of the financial advisor (airport). In the case of the opening up of the capital of one bank, the administrative decision to limit the scope of the opening to 49 percent may also have limited the number of potential buyers.
} 
14. The $\mathbf{2 0 0 4}$ budget retains the current expansionary fiscal stance, with the primary nonhydrocarbon deficit projected to stabilize near its 2003 Ievel. ${ }^{9}$ Current expenditures will rise as a result of a 25 percent increase in the minimum wage (SNMG), an allowance granted to civil servants in the education sector, and the upsurge in current transfers to public services. The budget includes DA 80 billion ( 1.5 percent of GDP) for reconstruction and also DA 77 billion for local development programs announced ahead of the elections.

Hydrocarbon revenues are projected to decline markedly, resulting in lower overall revenues and a projected overall budget deficit. ${ }^{10}$

\section{B. Medium-Term Policies}

15. The baseline medium-term scenario assumes an overall continuation of current economic policies and is based on the WEO oil price projections (Table 5). The fiscal stance remains broadly expansionary, although the gradual fall in oil prices triggers a modest consolidation. The scenario also involves a relatively strong growth of credit to the economy in the context of increasing bank liquidity, while the REER is assumed to remain constant at its estimated end-November 2003 level. It assumes that the pace of structural reforms remains tepid.

16. The scenario's results are mixed. While Algeria's external position continues to strengthen, the fiscal position weakens significantly, forcing the treasury to issue more securities and draw down its BA deposit. This monetary financing, coupled with an accumulation of net foreign assets, results in sustained liquidity expansion and a modest rise in inflation, while fiscal consolidation weighs somewhat on growth performance.

17. The scenario also highlights the risks of the current policy stance, which could, over time, endanger Algeria's internal balance:

- First, the slow pace of reforms implies that the projected rate of growth is not sufficient to rapidly reduce the high unemployment rate and the resulting social tensions.

- Second, the monetary creation induced by the fiscal deficit and by credit expansion constitutes a potential threat to macroeconomic stability and the banking sector. The increase in liquidity carries a significant inflationary risk. High liquidity may also encourage banks to follow a more aggressive credit policy, which, in turn, could generate additional nonperforming loans.

\footnotetext{
${ }^{9}$ The budget assumes a notional oil price of $\$ 19$ per barrel. However, staff projections detailed in Tables 2 and 5 are based on the World Economic Outlook (WEO) price assumption.

10 The decline in hydrocarbon revenues results mostly from the projected stabilization of the REER at its November 2003 level as well as from the projected slight drop in hydrocarbon export prices..
} 
Third, the risk of oil price (and to some extent hydrocarbon output) fluctuations makes the treasury's financial position vulnerable. The increase in the fiscal deficit in the case of a sharp and sustained drop in oil prices could generate a fiscal sustainability problem and require corrective measures that would have adverse consequences on growth. "Similarly, the public debt sustainability analysis indicates that a very large and sustained (but unlikely) adverse shock to GDP growth would result in high and growing debt levels (Table 6, line B2). However, a smaller GDP shock, such as a one-year drop in oil output resulting in a decline in overall GDP by one standard deviation, leads to higher but sustainable public debt ratios (Table 6 , line A2).

18. All in all, barring large and sustained shocks, Algeria's external position will remain strong over the medium term (Table 7 ). The standardized stress tests for external debt sustainability reveal that even large and low-probability shocks would not bring the debt ratio above the 1998 level (63 percent of GDP). Furthermore, the ratio would decline, after an initial increase, again suggesting that the external debt is sustainable.

\section{POLICY Discussions}

\section{A. Overview}

19. Since 1998, Fund surveillance has focused on the need to maintain macroeconomic stability and accelerate structural reforms. The authorities have responded favorably to Fund advice, which they consider a valuable input in the design and implementation of their policies. The stabilization achieved under the four years of Stand-By and Extended Arrangements completed in 1998 has been consolidated since then. Hawever, implementation of the structural policies recommended by staff has been slow, owing to social and political considerations, and to persistent administrative and institutional weaknesses. Consequently, private sector-led growth has remained disappointing since 1998. In a context of high oil revenues, the authorities have, therefore, adopted since 2001 an expansionary fiscal policy, in order to create jobs and improve living standards until private activity picks up.

20. The policy discussions focused on the risks of the current policy stance and the longer-term policy challenge of launching the economy on a sustained higher growth path. This objective requires an acceleration of productivity-enhancing reforms in a stable macroeconomic environment and an institutional framework supportive of private sector initiative and investment.

\footnotetext{
${ }^{11}$ A low price scenario is illustrated in Table 5 and line A3 of Table 6 . Assuming a plummeting in the oil price to $\$ 15$ per barrel from 2004 onward under unchanged policies, the deficit would jump to more than 13 percent of GDP and the treasury's account at the central bank would turn negative from the second half of 2005 (unless the treasury issues more securities). This scenario would result in an unsustainable rise in public debt.
} 
21. The authorities shared the view that steadfast implementation of the reform agenda is necessary. However, they also pointed out that expansionary policies have a role to play given the scale of the current level of unemployment. They expressed confidence in the success of their fiscal policy, noting the increase in growth already generated by high expenditures.

\section{B. Fiscal Policy}

22. As noted above, the authorities were determined to stimulate growth through continued fiscal stimulus. They stressed the role of public expenditure over the next few years to (a) provide for reconstruction and social needs and (b) continue to support growth in the absence of a marked pickup in private sector activity.

23. Staff expressed concerns about the procyclicality of expenditures in the wake of high hydrocarbon revenues. Recently high oil prices have played a crucial role in the maintenance of stability. In the event of a marked and durable drop in oil prices, the projected budget ceficit would increase sharply and could not be sustained indefinitely under unchanged policies. Staff also observed that the nonrecording of the quasi-fiscal operations of public banks in the budget (Box 1) overestimates (underestimates) the size of the overall surplus (deficit) by at least one percentage point of GDP. As noted in SM/03/28 (01/22/03), long-term considerations based on a permanent rent notion do not call for a loosening of the fiscal position achieved in 2001. ${ }^{12}$ In addition, (a) banks' quasi-fiscal operations; (b) contingent liabilities likely existing in the social security system and local municipalities, and (c) a current low return on government investment may call for greater fiscal discipline. Furthermore, monetary policy and commercial bank management are complicated by the large liquidity swings when volatile hydrocarbon revenues are not sterilized. Finally, staff expressed concern that the drive for structural reforms may have been dulled by the spur to growth resulting from the expansionary fiscal impulse.

24. While acknowledging Algeria's existing reconstruction and social needs, staff stressed that the current reliance on expansionary fiscal policies will, by itself, not be sufficient to generate sustainable growth. Although removing infrastructure bottlenecks calls for public investment, the recent surge in capital expenditure to GDP ratio has led to public investment in projects with low economic profitability (e.g., expansion of the railroad network, as assessed by the World Bank). Fiscal expansion can have only a temporary effect on activity. On the downside, it will inflate the relative size of government in the economy, complicate macroeconomic management, and carry the risk of further declining quality in new public investment projects. A sustained improvement in Algeria's growth performance requires an acceleration of productivity-enhancing stnuctural and institutional reforms.

${ }^{12}$ The stabilization fund created in 2000 does not involve any intergenerational transfer objective. 


\section{Box 1, Bank Recapitalization and Quasi-Fiscal Deficit}

Algeria still maintains a sizable and inefficient state-owned enterprise sector which largely relies on financial support from public banks. The continued provision of directed credit to large loss-making public enterprises has been the main factor of the fragility of public banks. Between 1991 and 2002, the Treasury repeatedly bailed out the public banks to enable them to meet prudential ratios. On average, these interventions amounted to about 4 percent of GDP per year over 1991-2002. ' New nonperforming loans accumulated since end-1999 imply a further provisioning and recapitalization of at least 3 percent of GDP ( 1 percent of GDP per year). Already in 2003, the government has "frozen" billions of dinars of public bank claims on some large state-owned companies.

Staff recommends removing from public banks the burden of being the financier of last resort for large loss-making enterprises in order to facilitate bank reform. Freeing public banks from their quasi-fiscal activities would at the same time increase transparency of fiscal policy, improve governance, and provide an incentive for subsequent public enterprise restructuring.

Directed credit should be replaced with temporary and explicit budget subsidies in the context of a well-defined restructuring program. These subsidies should be managed so as to gradually harden the budget constraints of these companies and to spread social costs over time. This temporary subsidization must be transparent, credible, and follow a preannounced action plan for phasing it out over time.

The recapitalization completed in 2002 is based on end- 1999 balance sheets.

25. Staff recommended a tightening of fiscal policy. For the short term, staff urged the authorities to curb public spending in the second half of 2004 , especially by restraining capital expenditures while giving priority to the subset of capital expenditures having strong complementarity to private sector development. For the longer term, staff suggested that public expenditures be stabilized as a percentage of NHGDP at a level consistent with medium-term fiscal constraints to avoid procyclicality. In addition, it recommended reorienting expenditure towards enhancing the social safety net to alleviate the social costs that may result from structural reform.

\section{Monetary Policy}

26. Monetary policy should be tightened. Staff noted that so far the rise in liquidity had been absorbed by the economy without undue pressures on domestic prices and international reserves. However, it cautioned that economic agents may not be willing to hold additional real money balances beyond a certain level. Staff drew the authorities' attention to the expansion of credit to the economy since late 2002 , which can, only partially be attributed to the pickup in activity. It also highlighted the potential consequences of such credit expansion on inflation and bank soundness. The authorities pointed out that, concerned by these risks, they had increased liquidity absorption in mid-2003. Staff emphasized that unless excess 
liquidity is fully mopped up, risks will continue to build up. However, monetary policy will not be fully effective unless banks follow a more profit-oriented approach and improve their risk evaluation capacity.

27. Staff recommended that the $B A$ relinquishes its role as a broker on the interbank market. It should limit its role to centralizing and disseminating information on concluded transactions, in order to let banks operate freely.

\section{External Policies}

28. The authorities confirmed their commitment to organizing trade in accordance with the multilateral framework, ahead of joining the WTO. Staff supported this commitment and welcomed the important legislative work done towards that objective. It pointed out, however, that the amendment to the draft budget law for 2004 approved by the National Assembly to ban imports of alcoholic beverages is in breach of WTO rules and contrary to the principles underpinning Algeria's own trade reform. ${ }^{13}$

29. The authorities confirmed their intention to continue managing the exchange rate flexibly and avoiding any misalignment of the REER. Staff welcomed this principle guiding exchange rate policy. Both during the Article IV consultation mission and in subsequent contacts with the authorities, staff acknowledged that there is a large uncertainty in determining the appropriate level of the dinar exchange rate. While fiscal expansion and the strengthening of the external position may call for an appreciation of the exchange rate, other elements--tariff reform, low productivity growth, high unemployment, and a lack of diversification of the export base-point towards the opposite direction. Against this background, staff cautioned BA against targeting a further appreciation of the REER, as this policy could hamper the development of private activity, reduce employment opportunities, and hinder diversification of the narrow export base. An appreciation also further weakens the fiscal position, as it reduces the hydrocarbon tax revenues in dinar terms.

30. In this context, a further liberalization of the exchange system would deepen the foreign exchange market and foster a greater role of market forces in determining the exchange rate. An initial step could be granting greater freedom to nonhydrocarbon exporters to use their foreign exchange earnings and allowing banks to manage, within prudential limits, the resources mobilized in the form of foreign exchange deposits. Staff also recommended (a) an increase in the indicative ceiling under which foreign exchange requests for travel abroad are automatically granted by commercial banks, ${ }^{14}$ and (b) a streamlining of the procedures to sell foreign exchange for services transactions.

${ }^{13}$ The budget low for 2004 also bans the import of used trucks.

I4 The BA confirmed that this ceiling (put in place in 1997 when Algeria accepted its obligations under Article VIII) is indeed indicative and that transactions above the ceiling did take place when appropriate documentation proving the current account nature of the request for foreign exchange was provided. 
31. The authorities decided to engage in more active management of the country's debt. Staff provided advice on issues related to external assets and liabilities management, including the possible early prepayment of some sovereign debt (Box 2). ${ }^{15}$ In this context, staff urged the authorities to seek a quick resolution of issues concerning the debt to Russia.

\section{Box 2. Return to International Capital Markets}

The Algerian authorities consider the currently strong balance of payments position to be an opportune moment for reducing the country's external debt burden, diversifying its creditor base, and increasing its visibility. The return to international capital markets is not viewed as a fiscal necessity, but as a step enabling the Algerian economy to benefit from a better recognition of its potential by international investors.

In this context, ICM staff designed a strategy for Algeria's return to international capital markets and provided policy and technical advice on the implementation of this strategy. The strategy consists of three main courses of action:

- Engaging in a more active external debt management. ICM identified sovereign loans with a face value of US\$2.7 billion that could possibly be prepaid at par in the near future without protracted negotiations or penalties. If these prepayment operations were financed using foreign reserves, the estimated net savings (in net present value terms) would amount to about US $\$ 250$ million, or close to 10 percent of the principal prepaid. This operation would result in reducing interest payments by 0.1 percent of GDP in 2004, unless new domestic debt is issued to finance the buyback. A more comprehensive prepayment of debt would imply discussions with bilateral creditors-including London and Paris Club creditors - and a prior settlement of the issues related to the debt to Russia.

- Obtaining a sovereign credit rating. ICM advised to initiate immediately a request for a sovereign credit rating.

- Issuing a debut sovereign bond. ICM discussed the steps and modalities of issuing a bond in intemational capital markets. Staff stressed the need to include collective action clauses into sovereign bonds.

\footnotetext{
${ }^{15}$ The authorities have, nevertheless, not made a decision on the timing or the scope of such prepayment.
} 


\section{E. Structural Reforms}

\section{Banking Reform and FSAP follow-up}

32. The authorities are committed to reforming the banking sector. As detailed in Box 3, and in the accompanying Financial Sector Stability Assessment report, the public banks remain inefficient and continue to finance loss-making public enterprises. The authorities are currently moving on three fronts: modernizing the payments system (with World Bank assistance), strengthening bank licensing, and improving bank supervision. The Fund technical assistance in the latter area aims at building capacity in on-site and off-site inspections and at better risk assessment.

33. While supporting the authorities' initiatives, staff stressed that a comprehensive reform of the banking sector requires more decisive action. Staff emphasized that releasing banks from their function of financing the loss-making public enterprises should be at the core of reform. It recommended the replacement of directed credit to public enterprises with explicit subsidies from the budget in the context of an enterprise restructuring plan. It encouraged the authorities to complete the ongoing opening of the capital of one public bank and prepare the privatization of other banks and financial institutions.

34. The authorities shared the FSAP conclusions and welcomed staff advice to adopt a detailed action plan to implement the recommendations. Nevertheless, they did not commit themselves to privatizing all public banks over the medium term (Box 3).

35. The new ordinance on money and credit presented a mixed picture. Positive developments include the tightening of bank licensing conditions, the requirement for bank capital to be paid fully in cash, the greater flexibility in the choice of monetary policy instruments, the institutionalized coordination between the Ministry of Finance and BA, and the requirement for periodic reporting. However, the lifting of the requirement for the Treasury to assume the losses of BA if the latter's reserves are insufficient, and other dispositions on BA's and the banking commission's relations with the government could weaken the financial and operational independence of the central bank and of the banking commission.

\section{Other Structural Reforms}

36. Staff observed that reform progress has been slow over the past two years. It noted that an unattractive investment conditions and market imperfections continue to weigh on growth performance (Box 4). In addition to financial sector reform, staff called for accelerating reforms in the following priority areas: 


\section{Box 3. Financial Sector Assessment Program: Main Conclusions}

Algeria's financial sector is dominated by state-owned banks (90 percent of bank assets). Their portfolio is laden with treasury bills issued to replace nonperforming loans to public enterprises. Financial markets remain in infancy. Most public banks require further recapitalization (Box 1 ).

Unlike the tocal subsidiaries of reputed foreign banks, domestically-owned private banks are in a relatively precarious financial position. The recent failure of two private banks has, through contagion, weakened the financial positions of other locallyowned private banks. Given their limited size, the remaining private banks do not constitute a threat to the stability of the system. Furthermore, the new law on money and credit strengthened bank licensing requirements and efforts at improving bank supervision are underway with Fund assistance.

\section{Establishing an efficient financial system in Algeria requires action on three fronts:}

- Reform the institutions through which financial intermediation takes place. In this respect, increasing the market share of quality private banks will boost competition and raise the level of professional qualification.

- Improve the framework in which financial institutions operate. This requires a set of continuous reforms in the legal, accounting, and judicial areas. However, the most urgent needs are to modernize the payments system and to strengthen bank supervision.

- Modulate the hydrocarbon-induced liquidity and credit cycles that curtail banks' risk-taking. This rests first on immunizing public expenditure from swings in hydrocarbon revenues. It also requires coordination between fiscal policy and liquidity management. 


\section{Box 4. Disfunctioning of the Cement Market}

Boosted by government expenditures and reconstruction needs, the demand for cement has surged since 2001. Although the theoretical production capacity is 11 million tons per year, actual output has never exceeded 8-9 million tons because public plants, which had a monopoly on domestic production until 2003 , have proved unable to function even close to full capacity. The imbalance between domestic demand and supply attracted the interest of private investors and importers. A major Middle Eastern cement company recently inaugurated a new plant, with a productive capacity of 2 million tons per year.

The market does not function properly. The public cement factories price their cement based on a weighted average of the local production cost--plus a mark upand of the import price. The local production cost is kept artificially low owing to the implicit subsidization of domestic gas prices-an essential cost component. The public companies' non profit-maximizing policy can distort the functioning of the market, as the cost to private importers is necessarily above the weighted average price.

In the wake of high demand and limited productive capacity, the public sector has increased its import volumes. As a result, the price of public cement increased moderately because of the higher weighted average price. However, owing to the still unfulfilled demand, private sector imports surged and the price of privately imported cement jumped up to 150 percent of the price of cement sold by the public sector, further illustrating the disfunctioning of the market.

With the objective of increasing efficiency, the government decided to sell 51 percent of the capital of three (out of twelve) state-owned cement plants. Ten foreign cement manufacturers expressed interest. However, at the end of the bidding process, only one compliant bid remained. The government cancelled the whole operation as the financial offer was deemed too weak. The government plans to Iestart the process in the near future after taking into account the concerns expressed by potential investors on the initial tender's strict terms and conditions. 
Privatization. Staff noted the government's willingness to move ahead pragmatically, in consultation with its social partners. However, no tangible results have been recorded yet and attempts in 2003 at privatizing some companies (e.g., cement factories) failed. The mission encouraged the authorities to move forward, taking into account investors' needs while strengthening the social safety net to cushion the impact of any labor retrenchment. The success of the privatization process will also depend on the progress made in the improvement of the investment climate, strengthening market institutions, and transparency.

- Improvement of economic institutions. Staff emphasized that the establishment and efficient functioning of institutions is no less important than physical infrastructure for a good performance of market economies. It urged the authorities to ensure the creation of a genuine real estate market in residential, industrial, and commercial premises ${ }^{16}$ to continue to improve the functioning of key public services (customs and tax administration, and the judiciary) while strengthening the quality of the services provided by public utility companies (Box 5 ).

\section{Box 5. Liberalization of Telecommunications}

In 1999, the government put in place with World Bank assistance a comprehensive strategy to liberalize the telecommunications sector.

The government succeeded in implementing substantial elements of this strategy. A new regulatory body was established. All public assets (fxxed lines and GSM services) in the telecommunications sector were transferred to a new public enterprise, Algérie Télécom, created in 2002. A second GSM license was auctioned to an international investor.

However, the incomplete corporatization of Algérie Télécom is hampering a sound development of the sector. The opening balance sheet of Algérie Télécom has not yet been established, in part because the government did not decide on time on the amount of existing debt that should be transferred to Algèrie Télécom. Consequently, Algerie Télécom has not been able to secure the financing resources needed for its capacity expansion. It bas, therefore, not been in a position to effectively compete with the second GSM licensee and to bring about improved services and lower prices for consumers.

Meanwhile, the liberalization of the market is continuing. In particular, preparation for the issuance of a third GSM license is under way.

${ }^{16}$ Private investors often complain about difficulties in acquiring land and about property rights uncertainties. 
Active labor market policies. Staff stressed that increased flexibility in labor legislation together with reduced taxation of the wage bill, should increase employment elasticity to growth. In addition, these reforms, coupled with a modernization of domestic trade, should contribute to limiting expansion of the informal sector.

\section{F. Governance, Data and Other Issues}

37. Transparency and governance. Staff welcomed the progress made through strengthening tax and customs administrations, revising the procurement code and the law on money and credit, publishing BA's annual report, and authorizing the publication of Article IV consultation staff reports. However, much remains to be done to improve transparency, inclusiveness, and accountability. In particular, there is a need to (a) better disseminate economic information; (b) adopt a more proactive attitude on the part of agencies monitoring the use of public funds; (c) strengthen the independence and efficiency of the judicial system; and (d) resume the publication of the Audit Office reports.

38. Anti-Money laundering (AML). Algeria has established a Financial Intelligence Unit; however, little progress has been achieved in the adoption of an AML law. A World Bank-led assessment of the AML framework is under way.

39. Technical assistance. The authorities expressed satisfaction with Fund assistance on tax and customs administration reforms and stressed that in both areas implementation of the Fund recommendations was ongoing. They called for the intensification of Fund support to implement the remaining technical assistance recommendations. They also confirmed their interest in receiving technical assistance in government finance statistics, reserves management, monetary and exchange rate policy, banking supervision, and internal audit of the central bank.

40. The statistical system needs to be substantially strengthened. The September 2002 multisector statistical mission confirmed that, while the basic infrastructure for a sound statistical system is largely in place and local staff is generally well-trained and experienced, substantial weaknesses still prevail in many areas, particularly in data dissemination and timeliness, data coverage, poor or nonexistent source data, periodicity, and methodology. Staff regretted the delays in implementing the action plan recommended by STA to achieve the authorities' goal of subscribing to the SDDS.

41. Regional integration. The authorities expressed continuous interest in staff's involvement in the promotion of regional integration with Maghreb countries.

42. Staff urged the authorities to consider full participation in the enhanced HIPC initiative. It also encouraged them to consider voluntary advance repurchases to the Fund.

43. The authorities confirmed their interest for an early 2004 fiscal ROSC mission. 


\section{STAFF APPRAISAL}

44. Staff commends the authorities for the broad improvement in macroeconomic indicators in 2002 and 2003. Growth is picking up and unemployment is falling somewhat, inflation remains slow, the external position is strong, and Algeria is now net creditor to the rest of the world.

45. Against this backdrop, the government has eased the fiscal stance since 2001 . Confronted with mounting political and social demands, inadequate infrastructure, reconstruction needs generated by terrorism and natural disasters, the government let expenditures--especially capital expenditures - surge in an attempt to boost growth. The draft budget for 2004, which is marked by the pursuit of the reconstruction efforts as well as by electoral concerns, envisages a further rise in expenditures.

46. The government strategy has succeeded in boosting short-term growth. It has resulted in higher employment and in a rise in investment in agriculture and residential housing. Furthermore, as long as oil prices remain high, the loosening of the fiscal stance will endanger neither the external nor the treasury positions.

47. Nevertheless, risks arise from the adverse impact of the procyclical fiscal policy on long-term macroeconomic stability, and it is regrettable that the loosening of the fiscal stance has been accompanied by a marked slowdown in reform efforts. A continued fiscal expansion will boost growth performance only temporarily and is unlikely to reduce unemployment to more acceptable levels. Furthermore, the expansionary fiscal policy will not result in a sufficient increase in employment elasticity to growth and bears the risk of declining quality of investment. In addition, expenditure is higher than it should be to stabilize government wealth and maintain intergenerational equity. The current fiscal policy stance also increases the relative size of the government in the economy and could build up inflationary pressures.

48. Due to these risks, it is appropriate to adopt a less expansionary and less procyelical fiscal policy stance. In the short term, especially from the second part of 2004 , staff recommends a gradually tighter fiscal policy to limit the budget vulnerability to adverse developments in the oil market over the medium term. In the longer run, to avoid procyclicality, staff suggests that public expenditures be stabilized as a percentage of NHGDP at a level consistent with the medium-term fiscal constraint.

49. The surge in credit to the economy since $\mathbf{2 0 0 2}$ is a concern. While commending the authorities for keeping inflation low, staff considers that the surge in credit to the economy is likely to exceed the credit needs generated by higher economic activity and may result in inflationary pressures and nonperforming loans. Therefore, staff urges the BA to be more aggressive in mopping up all excess bank liquidity.

50. BA's continued commitment to implementing the managed float exchange rate regime in a flexible way is welcomed. However, the staff cautions against pursuing further the recent policy of generating an appreciation of the REER, as this policy could indeed 
hamper the development of private activity, lower employment opportunities, and hinder diversification of the export base. It would also further weaken the fiscal position. Staff recommends strengthening the role of market forces in determining the exchange rate by further liberalizing the exchange system.

\section{Staff strongly supports the authorities' decision to adopt a more active} management of external assets and liabilities. It welcomes the authorities' intention to prepay part of the debt, request a sovereign risk rating, and, in due course, return to international financial markets. An early settlement of bilateral debt issues with Russia is required to move to a comprehensive management of external liabilities. While welcoming the authorities' intention to grant debt relief on a case by case basis to HIPC eligible countries, staff urges Algeria to consider full participation in the enhanced HUC initiative.

52. Algeria needs to reinvigorate its structural and institutional reform efforts to put the economy on a sustainable path of higher growth, lower unemployment, improved social conditions, and reduced poverty. Despite the authorities' assurances that fiscal expansion is not a substitute for reforms, the reform pace has been increasingly slow since 2001. While acknowledging that the social, political, and electoral constraints that may have contributed to this slowdown are still prevalent, staff calls on the government to boost structural and institutional reforms in the following priority areas: (a) reforming banks; (b) privatizing/restructuring large public enterprises while replacing the current flow of directed credit received from public banks with direct and temporary budget subsidies; (c) improving the business climate through strengthening basic economic institutions; and (d) adopting active labor market policies. Staff suggests that an enhanced social safety net should cushion the impact of public sector restructuring in the event of labor retrenchment.

53. Staff welcomes the authorities' intention to improve statistics and their interest in the SDDS as a framework for statistics development; however, it regrets the delays in the implementation of the Fund technical assistance recommendations. Although systematic and timely transmission of data would improve Fund surveillance, the provision of data to the Fund is viewed by staff as broadly adequate for effective surveillance.

\section{Staft commends the authorities for their increased willingness to foster} transparency and urges them to improve governance drastically. The publication of the Article IV staff reports since 2000 is a positive sign. Nevertheless, further efforts are needed to disseminate economic information. Improved governance, including at the local and regional levels, is also needed. Institutions aimed at enforcing accountability need to be reinforced substantially and the results of their work published.

55. It is proposed that the next Article IV consultation with Algeria take place on the standard 12-month cycle. 
Table 1. Algeria: Selected Economic and Financial Indicators, 1999-2004

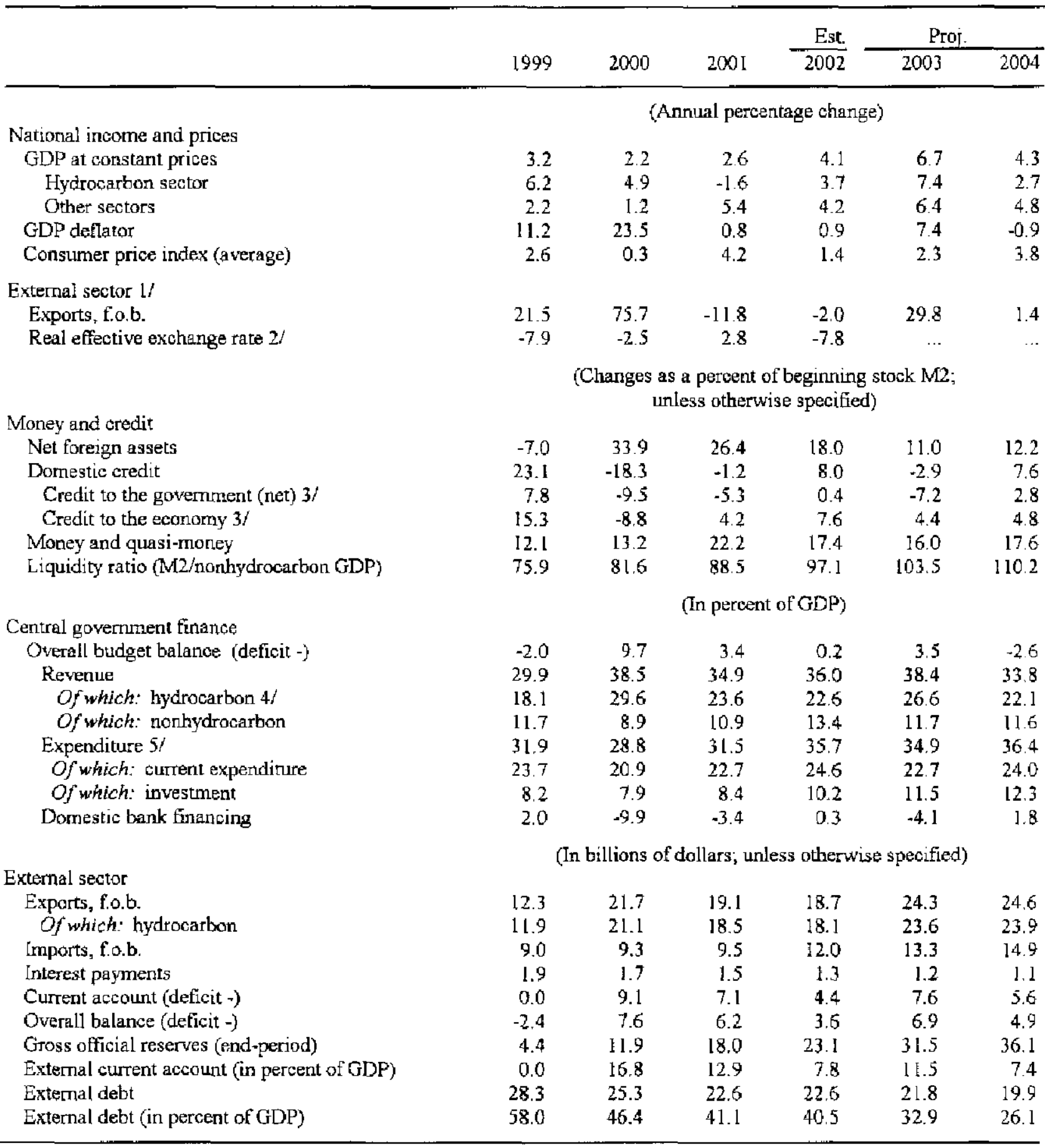

Sources: Algerian authorities; and Fund staff estimates and projections.

1/ In U.S. dollars terms.

2/ Annual average changes in the total trade-weighted INS index. A decrease in the index implies a depreciation.

$3 /$ Including the impact of financial restructuring package involving the swap of govenument bonds for public enterprises' corsmercial debt.

$4 /$ Including dividends on current protits paid by Sonatrach.

5/ Including special accounts, net lending, and allocation to the Rehabilitation Fund. 
Table 2. Algeria: Summary of Centrat Govemment Operations, 1999-2004

\begin{tabular}{|c|c|c|c|c|c|c|}
\hline & \multirow[b]{2}{*}{1999} & \multirow[b]{2}{*}{2000} & \multirow[b]{2}{*}{2001} & \multirow{2}{*}{$\frac{\text { Est. }}{2002}$} & \multicolumn{2}{|c|}{ Projection } \\
\hline & & & & & 2003 & 2004 \\
\hline & \multicolumn{6}{|c|}{ (In billions of Algerian dinars) } \\
\hline Budget revenue and grants & 973 & 1,578 & 1,479 & 1.603 & 1.960 & 1.784 \\
\hline Hydrocarbon revenue $1 /$ & 588 & 1,213 & 1,001 & 1,008 & 1,357 & 1,169 \\
\hline Nonhydirocarbon revenue & 381 & 365 & 462 & 595 & 596 & 612 \\
\hline Tax revenue & 339 & 350 & 398 & 483 & 533 & 569 \\
\hline Taxes on incorne and profits & 79 & 82 & 98 & 112 & 120 & 131 \\
\hline Taxes on goods and services & 163 & 165 & 179 & 223 & 245 & 264 \\
\hline Customs duties & 82 & 86 & 104 & 128 & 147 & 154 \\
\hline Registration and stamps & 14 & 16 & 17 & 19 & 19 & 21 \\
\hline Nontax revenues & 42 & 15 & 64 & 112 & 64 & 43 \\
\hline Grants & 4 & 0 & 16 & 0 & $\mathbf{B}$ & 4 \\
\hline Total expenditure & 1,034 & 1,178 & 1,321 & 1,551 & 1,748 & 1,912 \\
\hline Current expenditare & 769 & 856 & 964 & 1,098 & 1,160 & 1.264 \\
\hline Personnel expenditure & 284 & 290 & 324 & 346 & 380 & 442 \\
\hline Mudjahidins' pensions & 62 & 58 & 54 & 74 & 65 & 70 \\
\hline Material and supplies & 54 & 55 & 46 & 69 & 73 & 73 \\
\hline Current transfers & 246 & 292 & 391 & 472 & 516 & 566 \\
\hline Debt service & 124 & 162 & 148 & 137 & 125 & 113 \\
\hline Capital expenditure & 266 & 322 & 357 & 453 & 588 & 648 \\
\hline Budget balance & .62 & 400 & 158 & 53 & 213 & -128 \\
\hline Special accounts balance & -3 & -1 & -20 & -11 & 0 & 0 \\
\hline Net lerwding by the treasury & 0 & 1 & -7 & 31 & 36 & 11 \\
\hline Primary balance & 59 & 561 & 292 & 148 & 303 & -26 \\
\hline Overall balance & -65 & 399 & 145 & 10 & 177 & -139 \\
\hline Financing & 65 & 399 & -145 & -10 & -177 & 139 \\
\hline Bank $2 /$ & 64 & -407 & -145 & 16 & -210 & 94 \\
\hline Nonbank $3 /$ & 73 & 106 & 112 & 49 & 132 & 135 \\
\hline \multirow[t]{2}{*}{ Foreign } & -73 & -97 & -111 & -75 & -100 & -90 \\
\hline & \multicolumn{6}{|c|}{ (In percent of GDP) } \\
\hline Total revenue & 29.9 & 38.5 & 34.9 & 36.0 & 38.4 & 33.8 \\
\hline Hydrocarbon & 18.1 & 29.6 & 23.6 & 22.6 & 26.6 & 22.1 \\
\hline Nonhydrocarbon & 11.7 & 8.9 & 10.9 & 13.4 & 11.7 & 11.6 \\
\hline of which: tax revenue & 10.4 & 8.5 & 9.4 & 10.8 & 10.4 & 10.8 \\
\hline Totnl expenditure & 31.8 & 28.7 & 31.1 & 34.8 & 34.2 & 36.2 \\
\hline Current expenditure & 23.7 & 20.9 & 22.7 & 24.6 & 22.7 & 24.0 \\
\hline Capital expenditure & 8.2 & 7.9 & 8.4 & 10.2 & $\mathrm{t} 1.5$ & 12.3 \\
\hline Primary balance & 1.8 & 13.7 & 6.9 & 3.3 & 5.9 & -0.5 \\
\hline \multirow[t]{2}{*}{ Overall balanee } & -2.0 & 9.7 & 3.4 & 0.2 & 3.5 & -26 \\
\hline & \multicolumn{6}{|c|}{ (In percent of nonhydrocarbon GDP) } \\
\hline Nonhydrocarbon revenule & 16.1 & 14.7 & 16.5 & 19.9 & 183 & 17.0 \\
\hline Current expenditure & 32.6 & 34.5 & 34.4 & 36.7 & 35.6 & 35.1 \\
\hline Of which persontnel expenditure & 12.0 & 11.7 & 11.6 & 11.6 & 11.7 & 12.3 \\
\hline Capital expenditure & 11.3 & 13.0 & 12.8 & 15.1 & 18.1 & 18.0 \\
\hline Norhydrocarbon primary balance & -22.4 & -26.3 & -25.4 & -28.7 & -32.4 & -33.2 \\
\hline Nonhydrocarbon balance & -27.7 & -32.8 & -30.6 & -33.3 & -36.2 & -36.3 \\
\hline \multicolumn{7}{|l|}{ Memorandum iterns: } \\
\hline Nominal GDP (in billions of DA) & 3.248 & 4,099 & 4,242 & 4,455 & 5,107 & 5,278 \\
\hline Gross public debt (in percent of GDP) & 80.2 & 62.3 & 56.7 & 54,4 & 42.0 & 44.7 \\
\hline Of which: domestic & 32.6 & 25.0 & 23.6 & 22.0 & 18.8 & 23.5 \\
\hline Extertial & 47.6 & 37.3 & 33.1 & 32.4 & 23.2 & 212 \\
\hline $\begin{array}{l}\text { Gross public debt including identified } \\
\text { deficits (in percent of GDP) }\end{array}$ & 80.2 & 63.3 & 58.7 & 57.4 & 45.8 & 51.5 \\
\hline
\end{tabular}

Sounces: Data provided by the authorities; and Fund staff estimates and profections.

1/ Including dividends on eurrent peofits paid by Sonatrach.

2/ Starting in 2002, includes CNEP.

$3 /$ Including privatization receipts.

CInternational Monetary Fund. Not for Redistribution 
Table 3. Algeria: Monetary Survey, 1999-2004

\begin{tabular}{|c|c|c|c|c|c|c|}
\hline & \multirow[b]{2}{*}{1999} & \multirow[b]{2}{*}{2000} & \multirow[b]{2}{*}{2001} & \multirow{2}{*}{$\frac{\text { Est. }}{2002}$} & \multicolumn{2}{|c|}{ Projections } \\
\hline & & & & & $20031 /$ & 2004 \\
\hline & \multicolumn{6}{|c|}{ (In billions of Algerian dinars; at end of the period) } \\
\hline Foretgn assets (net) & 170 & 776 & $1,31 !$ & 1,756 & 2,075 & 2,488 \\
\hline Foreign assets (BA) & 330 & 919 & 1,446 & 1,869 & 2,138 & 2,529 \\
\hline Foreign liabilities (BA) & 157 & 145 & 132 & 126 & 73 & 51 \\
\hline Foreign assets (comm. banks) & 28 & 28 & 32 & 50 & 40 & 41 \\
\hline Foreign liabilities (comm. banks) & 31 & 27 & 35 & 37 & 30 & 31 \\
\hline Net domestic assets & 1,620 & 1,249 & 1,164 & $1,1,50$ & 1,294 & 1,475 \\
\hline Domestic credit & 1,999 & 1,671 & 1,648 & 1,845 & 1,763 & 2,018 \\
\hline Credit to government (net) $2 /$ & 848 & 678 & 570 & 579 & 369 & 463 \\
\hline Credit to the economy $2 /$ & 1,151 & 994 & 1,078 & 1,267 & 1,394 & 1,555 \\
\hline Other items net $3 /$ & -379 & -422 & -483 & -695 & -468 & -543 \\
\hline Money and quasi-money (M2) & 1,789 & 2,025 & 2,475 & 2,906 & 3,370 & 3,963 \\
\hline Money & 905 & 1,048 & 1,239 & 1,416 & 1,683 & 1,980 \\
\hline \multirow[t]{2}{*}{ Quasi-money } & 884 & 977 & 1,237 & 1,489 & 1,686 & 1,983 \\
\hline & \multicolumn{6}{|c|}{ (Percent change over 12-month period) } \\
\hline Money and quasi-money (M2) & 12.1 & 13.2 & 22.2 & 17.4 & 16.0 & 17.6 \\
\hline of which: Money & 9.5 & 15.8 & 18.2 & 14.4 & 18.9 & 17.6 \\
\hline Net domestic assets (banking system) & 23.1 & -22.9 & -6.8 & -1.2 & 12.5 & 139 \\
\hline \multirow[t]{2}{*}{ Of'which: Credit to the economy } & 27.0 & -13.6 & 8.5 & 17.5 & 10.0 & 11.6 \\
\hline & \multicolumn{6}{|c|}{ (Changes as a percent of beginuing money stock) } \\
\hline Money and quasi-money (M2) & 12.1 & 13.2 & 22.2 & 17.4 & 16.0 & 17.6 \\
\hline Foreign assets & -7.0 & 33.9 & 26.4 & 18.0 & 11.0 & 12.2 \\
\hline Nel domestic assets & 19.1 & -20.7 & -4.2 & -0.6 & 5.0 & 5.4 \\
\hline Domestic credit & 23.1 & -18.3 & -1.2 & 8.0 & -2.8 & 7.6 \\
\hline Net credit to government & 7.8 & -9.5 & -5.3 & 0.4 & -7.2 & 2.8 \\
\hline Credit to the economy & 13.3 & -8.8 & 4.2 & 7.6 & 4.4 & 4.8 \\
\hline \multicolumn{7}{|l|}{ Memorandum items: } \\
\hline Liquidity ratio (e.op. M2/GDP) & 55.1 & 49.4 & 58.4 & 65.2 & 66.0 & 75.1 \\
\hline Liquidity ratio (e.o.p. M2/NHGDP) & 75.9 & 81.6 & 88.5 & 97.1 & 103.5 & 110.2 \\
\hline Domestic credit/GDP & 61.5 & 40.8 & 38.8 & 41.4 & 34.5 & 38.2 \\
\hline Net credit to govemment/GDP & 26.1 & 16.5 & 13.4 & 13.0 & 7.2 & 8.8 \\
\hline Nominal GDP in billions of DA & 3,248 & 4,099 & 4,242 & 4,455 & 5,107 & 5,278 \\
\hline Nominal NHGDP in billions of DA & 2,357 & 2,483 & 2,798 & 2,994 & 3,256 & 3,597 \\
\hline Exchange rate (e.o.p.) & 69.3 & 75.3 & 77.8 & 79.7 & $\ldots$ & $\ldots$ \\
\hline
\end{tabular}

Sources: Bark of Algeria; and Fund staff estimates and projections.

1/ Projections are based on banks balance sheets exchuding the two liquidated banks.

2/ This includes the impact of bank restructuring packages. The conversion of bank claims on public enterprises in bank claims on the government results, other things being equal, in a decrease of eredit to the economy and an equal inorease in credit to the government. The flow of new credits in 2003 exceeds the stock difference between 2002 and 2003 , because of the liquidation of two private banks.

$3 /$ This includes the debt-rescheduling proceeds blocked in special accounts at the Bank of Algeria. 
Table 4. Algeria: Balance of Payments, 1999-2004

(In billions of U.S. dollars; unless otherwise indicated)

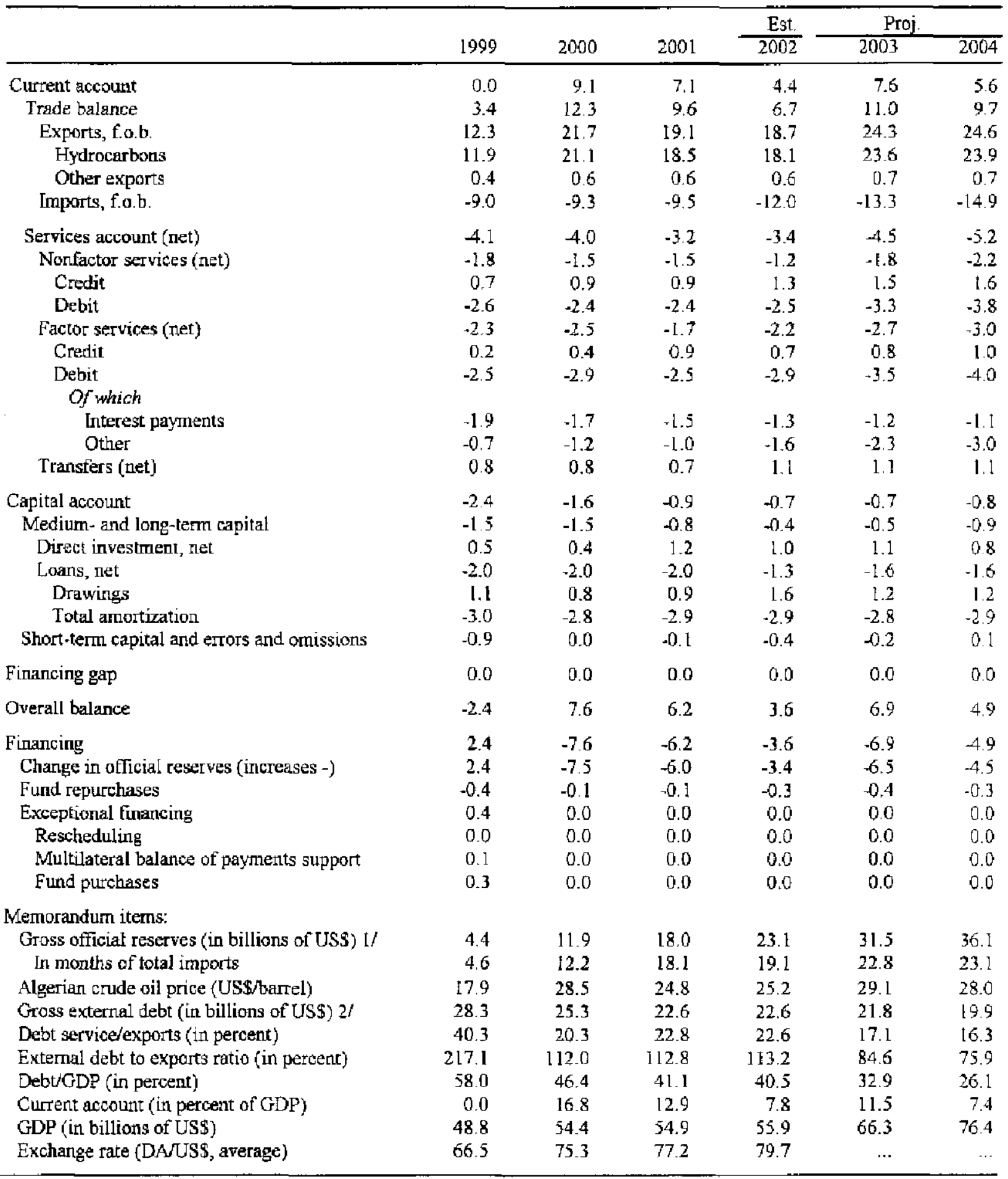

Sources: Bank of Algeria (through 2000 data); and Fund staff estimates and projections.

l/ According to the information provided by the Bank of Algeria all ofinicial reserves are liquid.

2/ According to the Bank of Algeria, its actual data inlcude short-term debt, use of Fund resources and debt to Russia. 
Table 5. Algeria: Illustrative Medium-Term Sccuarios, 2002-08

\begin{tabular}{|c|c|c|c|c|c|c|c|c|c|c|c|c|}
\hline & \multirow[b]{3}{*}{2002} & \multirow{3}{*}{$\frac{\text { Proj }}{2003}$} & \multicolumn{5}{|c|}{ Baselint Scenario Based on WEO Oil Prices } & \multirow{2}{*}{\multicolumn{5}{|c|}{$\begin{array}{l}\text { Scenario with Low Oil Prices } \\
\text { Projection } 1 /\end{array}$}} \\
\hline & & & & & jection & & & & & & & \\
\hline & & & 2004 & 2005 & 2006 & 2007 & 2008 & 2004 & 2005 & 2006 & 2007 & 2008 \\
\hline \multicolumn{13}{|l|}{ Main assumptions } \\
\hline $\begin{array}{l}\text { Oil prices (USS per barrel) } \\
\text { Hydrecarbon GDP (volume change) }\end{array}$ & $\begin{array}{r}25.2 \\
3.7\end{array}$ & $\begin{array}{r}29.1 \\
7.4\end{array}$ & $\begin{array}{r}28.0 \\
2.7\end{array}$ & $\begin{array}{r}25.0 \\
4.4\end{array}$ & $\begin{array}{r}24.0 \\
6.8\end{array}$ & $\begin{array}{r}23.5 \\
7.1\end{array}$ & $\begin{array}{r}23.5 \\
3.5\end{array}$ & $\begin{array}{r}15.0 \\
2.7\end{array}$ & $\begin{array}{r}15.0 \\
4.4\end{array}$ & $\begin{array}{r}15.0 \\
6.8\end{array}$ & $\begin{array}{r}15.0 \\
7.1\end{array}$ & $\begin{array}{r}15.0 \\
3.5\end{array}$ \\
\hline \multicolumn{13}{|l|}{ Selected economic and financial indicators } \\
\hline $\begin{array}{l}\text { Real GDP (in percentage change) } \\
\text { Nonhydrocarbon GDP (in percentage change) } \\
\text { CPI inflation (in percen, average) }\end{array}$ & $\begin{array}{l}4.1 \\
4.2 \\
1.4\end{array}$ & $\begin{array}{l}6.7 \\
6.4 \\
2.3\end{array}$ & $\begin{array}{l}4.3 \\
4.8 \\
3.8\end{array}$ & $\begin{array}{l}4.3 \\
4.2 \\
4.0\end{array}$ & $\begin{array}{l}4.8 \\
4.2 \\
4.2\end{array}$ & $\begin{array}{l}4.9 \\
4.1 \\
4.4\end{array}$ & $\begin{array}{l}4.0 \\
4.1 \\
4.5\end{array}$ & $\begin{array}{l}4.3 \\
4.8 \\
3.8\end{array}$ & $\begin{array}{l}4.3 \\
4.2 \\
4.0\end{array}$ & $\begin{array}{l}4.8 \\
4.2 \\
4.2\end{array}$ & $\begin{array}{l}4.9 \\
4.1 \\
4.4\end{array}$ & $\begin{array}{l}4.0 \\
4.1 \\
4.5\end{array}$ \\
\hline $\begin{array}{l}\text { Monetary expansion (M2, in percentage cliange) } \\
\text { Nel credit to the govemment (in percent of GDP) } \\
\text { Credit to the economy (in percent of GDP) } \\
\text { Liquidity ratio (M2/nonhydrocarbon GLP) }\end{array}$ & $\begin{array}{l}17.4 \\
13.0 \\
28.4 \\
97.1\end{array}$ & $\begin{array}{r}16.0 \\
7.2 \\
27.3 \\
103.5\end{array}$ & $\begin{array}{r}17.6 \\
8.8 \\
29.5 \\
110.2\end{array}$ & $\begin{array}{r}13.5 \\
11.4 \\
30.9 \\
115.5\end{array}$ & $\begin{array}{r}12.7 \\
13.6 \\
31.6 \\
119.8\end{array}$ & $\begin{array}{r}13.3 \\
15.5 \\
32.1 \\
124.8\end{array}$ & $\begin{array}{r}12.5 \\
17.4 \\
32.8 \\
129.0\end{array}$ & $\begin{array}{r}14.7 \\
19.3 \\
33.5 \\
109.3\end{array}$ & $\begin{array}{r}10.9 \\
30.8 \\
34.6 \\
112.2\end{array}$ & $\begin{array}{r}11.4 \\
40.7 \\
34.9 \\
115.0\end{array}$ & $\begin{array}{r}12.6 \\
49.9 \\
35.3 \\
119.0\end{array}$ & $\begin{array}{r}12.1 \\
59.3 \\
35.9 \\
122.6\end{array}$ \\
\hline $\begin{array}{l}\text { Ovarall budget balane (in percent of GDP) } \\
\text { Nonhydrocarbon primaty balance (in percent of NHGDl') } \\
\text { Hydrocarbon revenues (in percent of GDP) } \\
\text { Nonhydrocarboin revenues (in percent of GDP) } \\
\text { Expenditure (in percent of GDP) } 2 !\end{array}$ & $\begin{array}{r}0.2 \\
-28.7 \\
22.6 \\
13.4 \\
35.7\end{array}$ & $\begin{array}{r}3.5 \\
-32.4 \\
26.6 \\
11.7 \\
34.9\end{array}$ & $\begin{array}{r}-2.6 \\
-33.2 \\
22.1 \\
11.6 \\
36.4\end{array}$ & $\begin{array}{r}-4.1 \\
-31.7 \\
20.5 \\
12.7 \\
37.3\end{array}$ & $\begin{array}{r}-4.1 \\
-30.6 \\
19.9 \\
13.1 \\
37.2\end{array}$ & $\begin{array}{r}-3.6 \\
-29.5 \\
19.5 \\
13.3 \\
36.6\end{array}$ & $\begin{array}{r}-3.4 \\
-28.5 \\
19.2 \\
13.4 \\
36.0\end{array}$ & $\begin{array}{r}-12.2 \\
-34.1 \\
16.6 \\
13.1 \\
42.1\end{array}$ & $\begin{array}{r}-13.8 \\
-33.1 \\
15.5 \\
13.8 \\
43.1\end{array}$ & $\begin{array}{r}-13.7 \\
-32.4 \\
15.4 \\
13.7 \\
42.8\end{array}$ & $\begin{array}{r}-13.4 \\
-31.7 \\
15.4 \\
13.5 \\
42.3\end{array}$ & $\begin{array}{r}-13.6 \\
-31.1 \\
15.1 \\
13.3 \\
41.9\end{array}$ \\
\hline $\begin{array}{l}\text { Hydrocarbon Exports (in billions of USS) } \\
\text { Imports, fo.b. (in billions of US\$) } \\
\text { External current account (in percent of GDP) } \\
\text { International reserves (in billions of US\$) } \\
\text { In months of imports } \\
\text { External debt service (as percentage of exports of G\&S) } \\
\text { External debt (in percent of GDF) }\end{array}$ & $\begin{array}{r}18.1 \\
12.0 \\
7.8 \\
23.1 \\
19.1 \\
20.3 \\
40.5\end{array}$ & $\begin{array}{l}23.6 \\
13.3 \\
11.5 \\
31.5 \\
22.8 \\
17.3 \\
32.9\end{array}$ & $\begin{array}{r}23.9 \\
14.9 \\
7.4 \\
36.1 \\
23.1 \\
18.3 \\
26.1\end{array}$ & $\begin{array}{r}22.3 \\
15.6 \\
5.5 \\
39.0 \\
23.9 \\
17.9 \\
22.8\end{array}$ & $\begin{array}{r}22.7 \\
16.2 \\
5.8 \\
41.8 \\
24.7 \\
18.2 \\
18.6\end{array}$ & $\begin{array}{r}23.8 \\
16.6 \\
6.8 \\
45.7 \\
26.4 \\
15.3 \\
14.4\end{array}$ & $\begin{array}{r}24.6 \\
17.5 \\
6.6 \\
49.3 \\
27.0 \\
16.3 \\
10.2\end{array}$ & $\begin{array}{l}14.6 \\
14.9 \\
-3.4 \\
29.0 \\
18.7 \\
18.3 \\
30.1\end{array}$ & $\begin{array}{l}13.9 \\
15.5 \\
-4.8 \\
24.2 \\
15.0 \\
17.9 \\
26.1\end{array}$ & $\begin{array}{l}14.8 \\
16.1 \\
-4.0 \\
19.4 \\
11.6 \\
18.2 \\
20.9\end{array}$ & $\begin{array}{r}15.9 \\
16.5 \\
-2.9 \\
15.3 \\
8.9 \\
15.3 \\
16.1\end{array}$ & $\begin{array}{r}16.4 \\
17.4 \\
-3.5 \\
10.2 \\
5.6 \\
16.3 \\
11.3\end{array}$ \\
\hline $\begin{array}{l}\text { National savings (in percent of GDP) } \\
\text { Govenument } \\
\text { Nongovernment }\end{array}$ & $\begin{array}{l}38.3 \\
10.4 \\
27.9\end{array}$ & $\begin{array}{l}42.8 \\
15.0 \\
27.8\end{array}$ & $\begin{array}{r}39.1 \\
9.6 \\
29.5\end{array}$ & $\begin{array}{r}37.3 \\
8.5 \\
28.9\end{array}$ & $\begin{array}{r}37.5 \\
8.3 \\
29.2\end{array}$ & $\begin{array}{r}38.6 \\
8.3 \\
30.3\end{array}$ & $\begin{array}{r}38.3 \\
8.1 \\
30.2\end{array}$ & $\begin{array}{r}33.3 \\
1.9 \\
31.3\end{array}$ & $\begin{array}{r}32.1 \\
0.5 \\
31.5\end{array}$ & $\begin{array}{r}31.7 \\
0.3 \\
31.4\end{array}$ & $\begin{array}{r}32.8 \\
0.0 \\
32.8\end{array}$ & $\begin{array}{r}31.8 \\
-0.8 \\
32.6\end{array}$ \\
\hline $\begin{array}{l}\text { lnvestment (in percent of GDP) } \\
\text { Government }\end{array}$ & $\begin{array}{l}30.5 \\
10.2\end{array}$ & $\begin{array}{l}31.3 \\
11.5\end{array}$ & $\begin{array}{l}31.7 \\
12.3\end{array}$ & $\begin{array}{l}31.8 \\
12.6\end{array}$ & $\begin{array}{l}31.7 \\
12.4\end{array}$ & $\begin{array}{l}31.7 \\
12.0\end{array}$ & $\begin{array}{l}31.7 \\
11.4\end{array}$ & $\begin{array}{l}36.7 \\
14.2\end{array}$ & $\begin{array}{l}36.9 \\
14.3\end{array}$ & $\begin{array}{l}35.7 \\
14.0\end{array}$ & $\begin{array}{l}35.7 \\
13.4\end{array}$ & $\begin{array}{l}35.2 \\
12.8\end{array}$ \\
\hline Nongovernment & 20.4 & 19.7 & 19.5 & 19.2 & 19.3 & 19.8 & 20.3 & 22.5 & 22.5 & 21.7 & 22.3 & 22.5 \\
\hline
\end{tabular}

Sources: Algerian authorities, and Fund staff estimates und projections.

1f Hlustrative scenario aimed at showing the effects of lower oil prices under unchinged policies. hi particular, no additionial external borrowing is itsuntud.

2/ Including special ascounts and net kending. 
Table 6. Algeria: Public Sector Debt Sustainability Framework, 1998-2008 (III percent of 'GLF, waless olherwise maiculed)

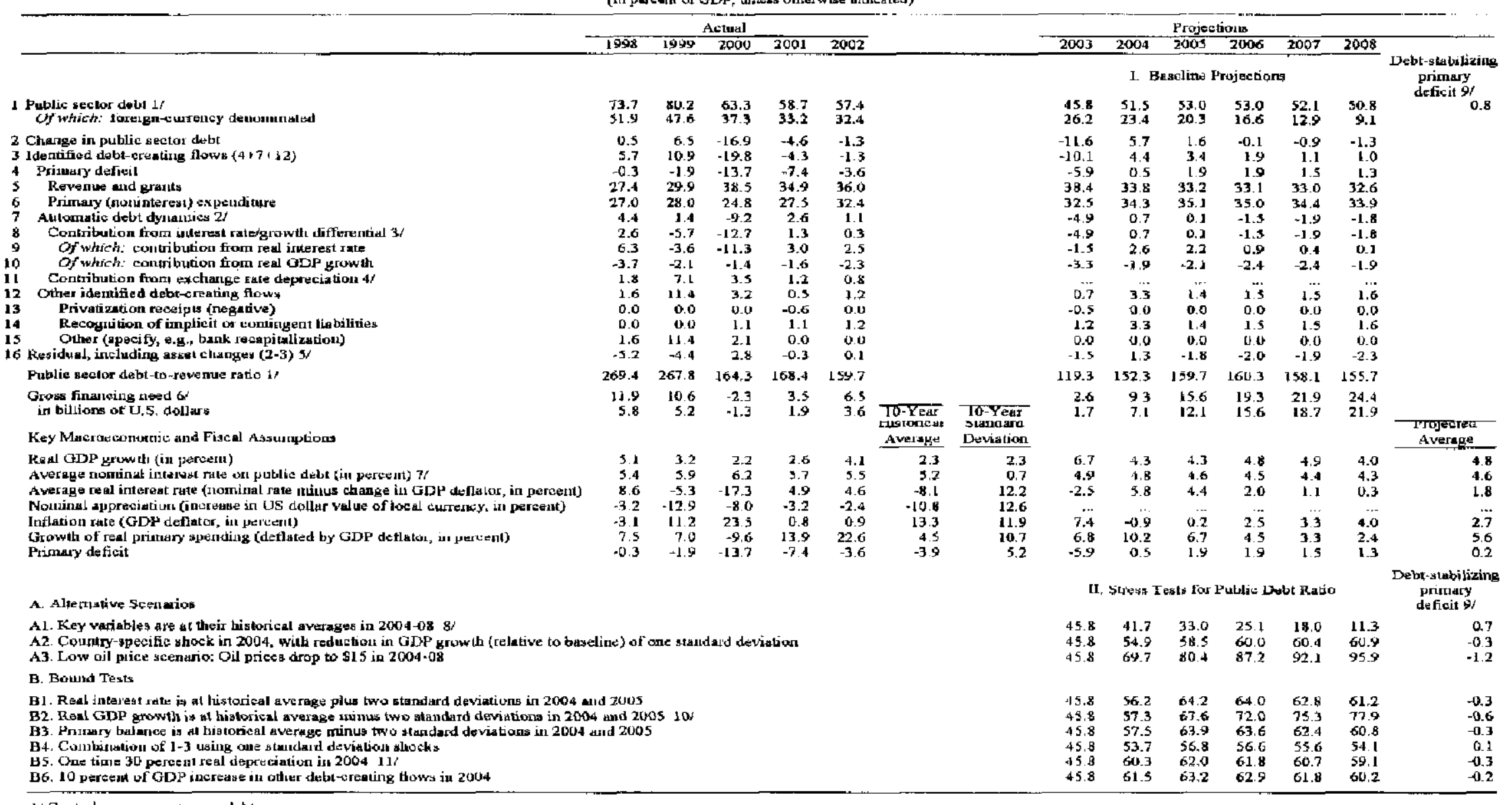

1f Central government gruss debt.

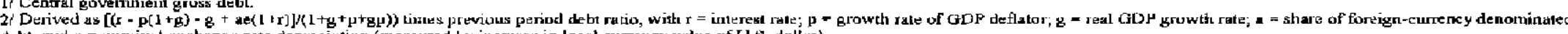

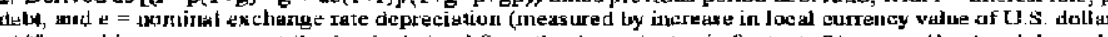

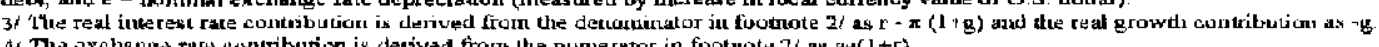

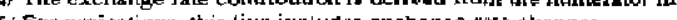

Defined us public seetor daficis phes anortizucion of the

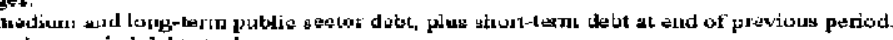

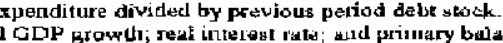

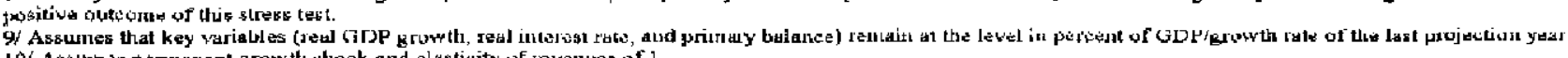

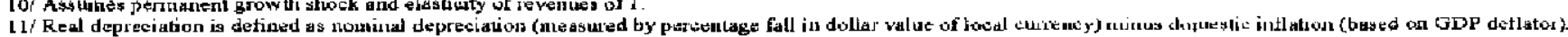


Table 7. Algeria: External Debt Sustainability Framework, 1998-200B (Ir. pereen of GDP. uriesy otherwise indi-nted)

\begin{tabular}{|c|c|c|c|c|c|c|c|c|c|c|c|c|c|c|}
\hline & & & Actual & & & & & & & & Projer & itions & & \\
\hline & 1998 & 1999 & 2000 & 2001 & 2002 & & & 2003 & 2004 & 2005 & 2006 & 2007 & 2008 & \\
\hline & & & & & & & & & 1. Ba & seline $\mathbf{P}$ & rojectias & & & $\begin{array}{l}\text { Debt-atabilizings } \\
\text { non-interest } \\
\text { current acciount } 7 /\end{array}$ \\
\hline 1 External debt & 63.2 & 58.0 & 46.4 & 41.1 & 40.5 & & & 32.9 & 26.1 & 22.8 & 28.6 & 14.4 & 10.2 & -1.1 \\
\hline 2 Change in textermul debt & -1.3 & $-5,3$ & $-11,6$ & $-5,3$ & -0.6 & & & -7.6 & -6.9 & -3.2 & -4.2 & -42 & -4.2 & \\
\hline 3 Identifind external debt-cruat ing inaws $(4+8+9)$ & 0.8 & -1.8 & -23.5 & -15.4 & -10.2 & & & -15.4 & -9.6 & -7.7 & -7.9 & -8.8 & -82 & \\
\hline 4 Current aceoumt deficit. exclusting interest payments & -2.2 & -3.8 & -20.0 & -156 & -10.1 & & & -13.2 & -8.8 & -6.8 & -6.8 & -7.7 & .7 .2 & \\
\hline Deffoit in balance of woods and services & -0.1 & -3.1 & -20.0 & -14.7 & -9.9 & & & -13.8 & -9.9 & -6.8 & -6.2 & -6.7 & .6 .1 & \\
\hline Exports & 22.6 & 26.7 & 41.5 & 36.4 & 35.8 & & & 39.0 & 34.4 & 32.0 & 31.3 & 31.0 & 30.6 & \\
\hline Imports & 22.5 & 23.6 & 21.3 & 21.7 & 23.9 & & & 25.1 & 24.5 & 25.2 & 25.1 & 24.3 & 24.5 & \\
\hline 8 Nut nou-dobt areating cupinal inflows (negative) & -1.0 & -0.9 & -0.8 & -2.1 & -1.7 & & & -1.7 & -1.0 & -1.1 & -1.1 & -1.1 & -1.1 & \\
\hline Aulomatic dubl dynamion $\mathrm{t}$ & 4.0 & 2.9 & -2.8 & 2.3 & 1.6 & & & -0.5 & 0.2 & 0.2 & c.0 & 0.0 & 0.1 & \\
\hline Contribution from tominal intereat rate & 4.0 & 3.8 & 3.2 & 2.8 & 2.3 & & & 1.8 & 1.4 & 1.3 & 1.1 & 0.8 & 0.6 & \\
\hline Contribution from real GDP growth & -3.3 & -2.0 & -1.1 & -1.2 & -1.6 & & & -2.3 & -1.2 & -1.1 & -1.1 & -0.9 & -0.5 & \\
\hline 2 Contribution from price and exchange rate dusurges 2 ; & 3.3 & 1.1 & -48 & 0.8 & 09 & & & & $2 \cdots$ & $\ldots$ & $\ldots$ & 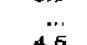 & $\ldots$ & \\
\hline 3 Residual, incl. change itı grass foreign assets (2-3 & -2.4 & -3.4 & i2.o & 10.1 1 & 9.7 & & & 7.9 & & & 3.7 & 4.6 & 4.0 & \\
\hline External debt-to-exports ratio (in percent) & 280.1 & 2171 & 1120 & 112.8 & 113.2 & & & 84.6 & 75.9 & 71.4 & 59.5 & 46.3 & 33.2 & \\
\hline $\begin{array}{l}\text { Grosu external financing need (in billions of US dollary) } 4 t \\
\text { in perenth of GDPP }\end{array}$ & $\begin{array}{l}4.7 \\
9.7\end{array}$ & $\begin{array}{l}3.6 \\
3.4\end{array}$ & $\begin{aligned}-6.1 \\
-11.2\end{aligned}$ & $\begin{array}{l}-3.8 \\
-7.0\end{array}$ & $\begin{array}{l}-0.9 \\
-1.6\end{array}$ & 10-Yent $\bar{l}$ & 10-Year & $\begin{array}{r}-4.3 \\
-6.4\end{array}$ & $\begin{array}{l}-2.3 \\
-3.1\end{array}$ & $\begin{array}{l}.0 .8 \\
-1.0\end{array}$ & $\begin{array}{l}-0.7 \\
-0.9\end{array}$ & $\begin{array}{l}-1.6 \\
-1.9\end{array}$ & $\begin{array}{l}-1.2 \\
-1.4\end{array}$ & \\
\hline Key Macroeconomic Assumptions & & & & & & $\begin{array}{l}\text { Historical St } \\
\text { Average } D \\
\end{array}$ & $\begin{array}{l}\text { Stardard } \\
\text { Deviation }\end{array}$ & & & & & & & $\begin{array}{l}\text { Projegtad } \\
\text { Avariage }\end{array}$ \\
\hline Real ODP gruwh (in percent) & 9.1 & 3.2 & 2.2 & 2.6 & 4.1 & 2. & 2.3 & 6.7 & 4.3 & 4,3 & 4.8 & 4.9 & 4.0 & 4.8 \\
\hline GDP deflator in US dellans (change in pereont) & -4.8 & -1.8 & 90 & -1.6 & -2.2 & -0.7 & 7.3 & 11.1 & 10.5 & -2.7 & -0.3 & 0.5 & 1.0 & 3.3 \\
\hline Nominal external int erest rate (in percent) & 6.3 & 6.1 & 6.1 & 6.0 & 5.8 & 6.5 & 0.6 & 5.1 & 5.0 & 4.9 & 4.8 & 4.7 & 4.5 & 4.9 \\
\hline Growth of exports (US dollar terms. in pereent) & -26.9 & 19.9 & 73.0 & -11.3 & 0.0 & 8.1 & 283 & 29.0 & 1.7 & -5.5 & 2.2 & 4.3 & 3.5 & 5.9 \\
\hline Gowth of imports (US dollar terms, in percert) & 5.5 & 0.2 & 1.6 & 1.8 & 21.6 & 4.1 & 9.7 & 14.8 & 12.5 & 4.4 & 3.9 & 2.2 & 5.7 & 7.3 \\
\hline Current zocount talar & 2.2 & 3.8 & 20.0 & 15.6 & 10.1 & 7.6 & 6.7 & 13.2 & 8. 8 & 6.8 & 6.8 & 7.7 & 7.2 & 8.4 \\
\hline Nat non-debt oreating oepital inflows & 1.4 & 0.9 & 0.8 & 2.1 & 1.7 & 0.8 & 0.7 & 1.7 & 1.0 & $\begin{array}{l}0.6 \\
1.1\end{array}$ & 1.1 & i. & 1.1 & 1.2 \\
\hline A. Altethative Sceturtios & & & & & & & & $\mathbf{u}$ & Iress Tes & its for $\mathrm{E}$ : & xterizial 5 & obt Rali & & $\begin{array}{l}\text { Dubt-stabilizinig } \\
\text { non-interest } \\
\text { current account } 6 f\end{array}$ \\
\hline Al. Key variables ara at their histcrical sverages in 2004-08 & & & & & & & & 32.9 & 32.8 & 30.2 & 27.5 & 26. 1 & 24.2 & 0.1 \\
\hline A2. Country-specific shock in 2004, with reduction in GD & owth (r) & Lative t & elin & of one & adard & vintion $6 x$ & & 32.9 & 26.7 & 23.5 & 19.1 & 34.7 & 10.4 & -1.2 \\
\hline A3. Low peice scenario: Oil prices drop to $\$ 15$ per barrel in & $\cos -08$ & & & & & & & 32.9 & 30.1 & 26.1 & 20.9 & 16.2 & 11.3 & -1.3 \\
\hline B. Bound Tests & & & & & & & & & & & & & & \\
\hline $\begin{array}{l}\text { B1. Nominal interest rate is at historical average plus two st } \\
\text { B2. Real GDP growth is at historical averge minus two tha }\end{array}$ & $\begin{array}{l}\text { xdard devi } \\
\text { land devia }\end{array}$ & $\begin{array}{l}\text { iations it } \\
\text { t1 ions in }\end{array}$ & 2004 at & $\begin{array}{l}2005 \\
12005\end{array}$ & & & & 32.9 & $\begin{array}{l}26.9 \\
28.4\end{array}$ & $\begin{array}{l}24.4 \\
27.6\end{array}$ & $\begin{array}{l}20.2 \\
23.8\end{array}$ & $\begin{array}{l}16.0 \\
20.0\end{array}$ & $\begin{array}{l}11.8 \\
16.2\end{array}$ & $\begin{array}{l}-1.1 \\
-1.3\end{array}$ \\
\hline deflator is at historical ave & minus in & ro starn & rd deviat & lions in 2 & 2004 and 150 & d 2005 & & 32.9 & 36.7 & 40.8 & 37.8 & 35.3 & 32.5 & -1.8 \\
\hline B4. Non-interest current account is at historioal average uni & $s$ two stay & ivdard de & viations $\mathrm{i}$ & $112004 \mathrm{a}$ & and 2005 & & & 32.9 & 40.6 & SO.4 & 46.2 & 41.8 & 37.5 & -1.3 \\
\hline B5. Combination of $2-5$ using one standard deviation shocks & & & & & & & & 32.9 & 43.5 & 53.4 & 47.6 & 41.6 & 35.8 & -1.7 \\
\hline B6. One time 30 percent nomingl depreciation in 2004 & & & & & & & & 32.9 & 46.7 & 45.8 & 43.1 & 40.9 & 38.4 & -1.9 \\
\hline
\end{tabular}

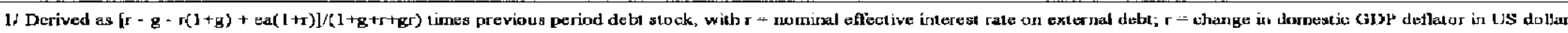

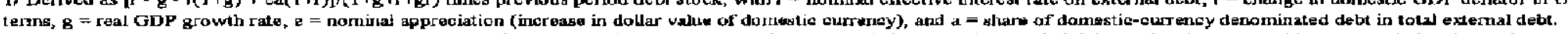

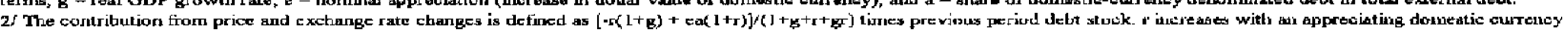
$(e=0)$ and rising inflation (based on GDP deflator).

3i. For projection, line irscludes prikce and exchange rale changes.

4t Defined as current account deficit. plus moortization on mediun- and long-terin debt, plus short-term debt al end of pravious period

Sf The key Wariable a include real GDP growth; nominal interest rate; delar deflator growth; and both non-imtertst currert account and nourdebt inflows in percent of GDP.

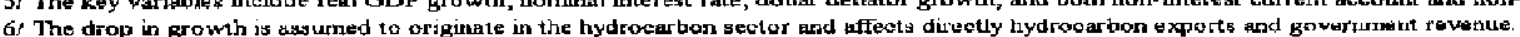

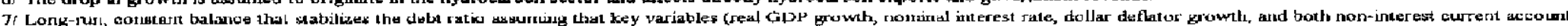

wrd nurn-debt inflows in perent of GDP, tema in al their levels of the last projection year. 
Table 8. Algeria: Indicators of External Vulnerability

(In percent of GDP, unless otherwise indicated)

\begin{tabular}{|c|c|c|c|c|c|c|c|}
\hline & \multirow[t]{2}{*}{$1995-99$} & \multirow[t]{2}{*}{2000} & \multirow[t]{2}{*}{2001} & \multirow{2}{*}{$\frac{2002}{\text { Estimate }}$} & \multicolumn{3}{|c|}{2003} \\
\hline & & & & & $\begin{array}{l}\text { Lafes } \\
\text { Exumate }\end{array}$ & Late: & Projection \\
\hline \multicolumn{8}{|l|}{ Financial indicators } \\
\hline Public sector debt $1 /$ & 79.7 & 52.3 & 56.7 & 54.4 & n.a. & & 42.0 \\
\hline Broad money (percent change, 12-month basis) $2 t$ & 20.6 & 13.2 & 22.2 & 17.4 & 14.8 & June & 16.0 \\
\hline Private sector credit (percent change, 12 month basis) $2 J$ & 7.7 & 15.7 & 117.4 & 63.7 & 34.6 & June & 10.0 \\
\hline 26 weak T-bill yield & r.s. & 8.0 & 5.7 & 1.8 & 2.0 & June & 2.0 \\
\hline 26 woek T-bill yield (real) & n.a. & 7.7 & 1.5 & 0.4 & 1.1 & June & -0.3 \\
\hline \multicolumn{8}{|l|}{ External Indicators } \\
\hline Exports (percent change, 12-month basis in USS) & 8.7 & 75.7 & -11.8 & -2.0 & 45.3 & June & 29.8 \\
\hline Imports (percent change. 12-month hasis in USS) & 0.0 & 4.3 & 1.5 & 26.7 & 10.7 & June & 10.6 \\
\hline Terms of Trade (percent change, 12 month basis) & 2.6 & 72.1 & -7.8 & -8.9 & n.a. & & 11.7 \\
\hline Cument account balance & 0.5 & 16.8 & 12.9 & 7.8 & n.a. & & 11.5 \\
\hline Capital and financial account balance & -56 & -2.9 & -1.6 & -1.3 & n.8. & & -1.1 \\
\hline Of which: Inward portfolio investment (debt securities etc.) & n.a. & n.a. & n.a. & n.a. & ก.a. & & n.a. \\
\hline Other investment (loans, trade credits etc.) & n.․․ & n.a. & n.a. & na & n.a. & & n._. \\
\hline Inward fortign direct investment in the form of debt or los & n.a. & n.a. & n.a. & n.a. & ก.a. & & a..... \\
\hline Gross officiał foreign exchange reserves (in billions of USS) & 5.1 & 11.9 & 18.0 & 23.1 & 30.4 & Oet. & 31.5 \\
\hline Central Bank short-term foreign liabilities (in billions of USS) & 0.4 & 0.2 & 0.2 & 0.2 & 0.3 & Aug. & 0.3 \\
\hline Central Bank foreign currency exposure (in USS) & n.a. & ח.a. & n.a. & n.a. & n.e. & & n...a. \\
\hline Short tern foreign assets of the financial sector (io USS) & n.a. & ก.a. & n.a. & n.a. & n.a. & & ก.9. \\
\hline Short term foreign liabilities of the financial sector (in billions of & 0.7 & 0.6 & 0.6 & 0.7 & 0.8 & Aug. & n.a. \\
\hline Foreign currency exposure of the financial sector (in US\$) & n.a. & n.a. & n.x. & n.a. & it.a. & & n.a. \\
\hline Official reserves in months of imports GS 3 ; & 5.6 & 12.2 & 18.1 & 19.1 & 22.2 & June & 22.8 \\
\hline Broad money to reserves & 4.4 & 2.2 & 1.7 & 1.6 & 1.4 & Aug. & 1.6 \\
\hline Total short term external debt to reserves $4 /$ & 1.1 & 0.3 & 0.2 & 0.1 & n.a. & & 0.1 \\
\hline Total external debt & 66.5 & 46.4 & 41.4 & 40.5 & n.a. & & 32.9 \\
\hline Of which : Public sector debt $1 /$ & 55.3 & $\mathbf{3 7 . 3}$ & 33.1 & 32.4 & n.a. & & 23.2 \\
\hline Total external debt to exponts GS $3 /$ & 2.5 & 1.1 & 1.1 & 1.1 & n.a. & & 0.8 \\
\hline External interest payments to exports GS $3 /$ & 0.2 & 0.1 & 0.1 & 0.1 & n.a. & & 0.0 \\
\hline External amortization payments to exports GS $3 /$ & 0.4 & 0.1 & 0.2 & 0.2 & a. & & 0.1 \\
\hline Exchange rate (per USS, period average) & 57.1 & 75.3 & 77.2 & 79.7 & 69.5 & Oet. & 77.1 \\
\hline REER appreciation $(+)(12$ month basis) $5 /$ & .1 .3 & -2.5 & 2.8 & -7.8 & -2.7 & Sept. & $\ldots$ \\
\hline \multicolumn{8}{|l|}{ Financial Market Indicators } \\
\hline Stock market index & n.a. & n.a. & n.a. & n.a. & a.a. & & n.a. \\
\hline Foteign currency debt rating & n.a. & n.a. & n.a. & n.a. & n.E. & & n.a. \\
\hline Spread of benchmark bonds (basis points, end of period) & n.a. & a.a. & n.a. & na. & n.a. & & a, $\mathbf{a}$. \\
\hline
\end{tabular}

1 Central government only.

2 Serien breaks in 1998 and 2003 due to change in status of tinancial intermediaries.

3/ Exports and imports on goods and services exchude factor incoms, in the with the Sth odition of the Batanoe of Payments Manual.

4/ Remaining maturity basis.

5/ Annual average changes in total trade-weighted INS index. A deorease in the index implies a depreviation. Consumbr prioe

indice are used The September 2003 observation is the change relative to Septenber 2002. 
Algeria: Relations with the Fund

(As of September 30, 2003)

\section{A. Financial Relations}

Membership Status Joined 9/26/63; Article VIII

General Resources Account

Quota

Fund holdings of currency

Reserve position in Fund

SDR Department

Net cumulative allocation

Holdings

Outstanding Purchases and Loans

Extended arrangements

Contingency and Compensatory
SDR Million

$1,254.70$

$1,938.63$

85.08

SDR Million

128.64

6.46

SDR Million

671.13

83.81
Percent of Quota

100.00

153.39

6.78

Percent of Allocation 100.00

5.03

Percent of Quota

53.49

6.68

Financial Arrangements

$\begin{array}{lcccc}\text { Type } & \begin{array}{c}\text { Approval } \\ \text { Date }\end{array} & \begin{array}{c}\text { Expiration } \\ \text { Date }\end{array} & \begin{array}{c}\text { Amount } \\ \text { Approved } \\ \text { (SDR Million) }\end{array} & \begin{array}{c}\text { Amount } \\ \text { Drawn } \\ \text { (SDR Million) }\end{array} \\ \text { CCFF } & 5 / 07 / 99 & -- & 223.50 & 223.50 \\ \text { EFF } & 5 / 22 / 95 & 5 / 21 / 98 & 1,169.28 & 1,169.28 \\ & & & & \\ \text { Stand-by } & 5 / 27 / 94 & 5 / 22 / 95 & 457.20 & 385.20 \\ \text { Stand-by } & 6 / 03 / 91 & 3 / 31 / 92 & 300.00 & 225.00\end{array}$

Projected Obligations to Fund (SDR million; based on existing use of resources and present holdings of SDRs):

\begin{tabular}{lcrrrrr} 
& Overdue & \multicolumn{5}{c}{ Forthcoming } \\
\cline { 4 - 7 } & & 2003 & 2004 & 2005 & 2006 & 2007 \\
\hline Principal & 0.00 & 90.21 & 250.75 & 181.85 & 126.61 & 84.41 \\
Charges/interest & 0.00 & 4.50 & 14.16 & 9.38 & 5.81 & 3.35 \\
Total & 0.00 & 94.71 & 264.91 & 191.23 & 132.42 & 87.76
\end{tabular}




\section{B. Nonfinancial Relations}

\section{Exchange Rate Arrangement}

From January 21, 1974 to October 1, 1994, the exchange rate of the dinar was determined on the basis of a fixed relationship with a basket of currencies, adjusted from time to time. On October 1, 1994, the Bank of Algeria introduced a managed float for the dinar through daily fixing sessions that included six commercial banks. This system has been replaced by an interbank foreign exchange market as of January 2, 1996. At the end of August 2003, the average of the buying and selling rates for the U.S. dollar was $\$ 1=\mathrm{DA} 77.86$, equivalent to SDR 1 = DA107.23. No margin limits are imposed on the buying and selling exchange rates in the interbank foreign exchange market, except for the dollar, where a margin of DA 0.017 has been established between the buying and selling rates of the Bank of Algeria for the dinar against the U.S. dollar.

Algeria maintains an exchange rate system which is free of restrictions on the making of payments and transfers for current international transactions.

\section{Latest Article IV Consultation}

The discussions for the 2002 Article IV consultation and post-program monitoring with Aigeria were held in Algiers from October 19 to November 2, 2002. The staff report (SM/03/28, 1/22/03) was discussed by the Executive Board on February 24,2003 . It was published.

\section{Technical Assistance}

- A MAE consultant visited Algeria four times in 1998-99 to assess the status of the banking system and provide advice in bank supervision

- MAE consultants visited Algiers in 2000 and 2001 to provide further advice in bank supervision.

- A STA mission visited Algiers in February 2000 and February-March 200! to provide assistance in the area of monetary statistics.

- A staff team from MED and MAE visited Algiers in April 2000 to advise on banking and monetary issues, and another staff team from MED and FAD visited in May 2000 to help clarify fiscal data issues.

- A FAD mission on tax administration visited Algiers in July 2000.

- A FAD mission on customs administration visited Algiers in July 2000 , and an expert on customs administration visited in March 2001

- A MAE mission (with MED participation) on review of monetary policy operations visited Algiers in November 2000.

- A FAD mission on budgetary procedures visited Algiers in February 2001. 
- Two FAD missions on tariff reform visited Algiers in January and March 2001.

- A FAD mission visited Algiers in December 2001 to advise on the modernization of tax administration.

- A MAE consultant visited Algiers in January, April, July, and October 2002 to assist the Bank of Algeria to develop its bank supervision capability.

- From May 2001 to July 2002, FAD organized periodic visits of a tax administration expert to assist the authorities in establishing a large taxpayers unit.

- A FAD mission visited Algiers in June-July 2002 to advise on the ongoing process of customs modernization.

- A STA multisector mission visited Algiers during September 4-17, 2002 to assess the system of macroeconomic statistics, including monetary, balance of payments, public finance and national accounts statistics, and price indices.

- A FAD consultant visited Algiers in September-October 2003 to advise on the ongoing process of customs modernization.

- A MFD consultant visited Algiers in October 2003 to advise on bank liquidation. Financial Sector Assessment Program (FSAP)

Algeria participated in the FSAP. Missions were conducted in March and June 2003. Conclusions were discussed in October 2003.

\section{Resident Representative/Advisor}

None. 


\section{Algeria: Financial Relations With The World Bank \\ (As of November 3,2003 )}

The World Bank portfolio in Algeria has a total of 13 active operations and 60 closed loans, with cumulative net commitments of $\$ 4.6$ billion, of which $\$ 2.9$ billion have been repaid. Net commitments for the 13 current operations amount to $\$ 541.8$ million.

In the 1990s, Bank assistance fluctuated, with strong support in FY 1995 and FY 1996 to the stabilization and adjustment program (\$759 million). The security situation as well as the lack of managerial and technical capacity of some implementing agencies affected project implementation. The quality of the portfolio improved following the closing of an ineffective stock of aged projects. A strategy for improving quality at entry and portfolio performance was put in place in February 2003 and is now being implemented. A Country Procurement Assessment Review was finalized in 2003

During the past few years, Bank relations with Algeria have been revived in a climate of openness and collaboration. The establishment of a liaison office in January 2002 has proved to be crucial and successful in improving relations, moving the policy dialogue forward, and improving portfolio implementation. A new Country Assistance Strategy was presented to the Board on June 12,2003. The main goal of the Bank's partnership will be to support the reforms laid out in the comprehensive national development agenda to sustain growth, generate employment, and reduce poverty and vulnerability. The Bark's strategic assistance will focus its support on (i) fiscal sustainability and hydrocarbon revenue management; (ii) removing constraints to private sector-led growth; and (iii) articulating and implementing a strategy for better service delivery. To that effect, a program of analytical and advisory services, institutional capacity building, demand driven lending and/or risk mitigation through structured loans, hedging products, and guarantees is being implemented

Lending was renewed in FY 2000 amounting to $\$ 97.5$ million, with three operations covering two strategic fronts: technical assistance for institutional strengthening and reforms, and assistance for emergency situations. Projects approved in FY 2001 and FY 2002, amounting to $\$ 41.7$ million and $\$ 30.7$ million respectively, continued to support the Algerian government in its efforts to implement policy and institutional reform in the energy and mining sector, transport sector, budget system and financial system infrastructure modernization, as well as mortgage finance. In FY 2003, the Board approved an Urban Natural Hazard Vulnerability project ( $\$ 88.5$ million) to respond to the impact of the November 2001 floods and a Second Rural Employment project ( $\$ 95$ million).

Key pieces of analytical work were completed, including a social expenditure review, a private sector assessment, a macroeconomic strategy note, an investment climate note and a financial sector assessment report. In addition, policy dialogue and advice are being provided to develop sector strategies in rural development and agriculture, housing, water resource management and education. 


\section{Algeria: Financial Relations with the World Bank}

(As of November 3, 2003)

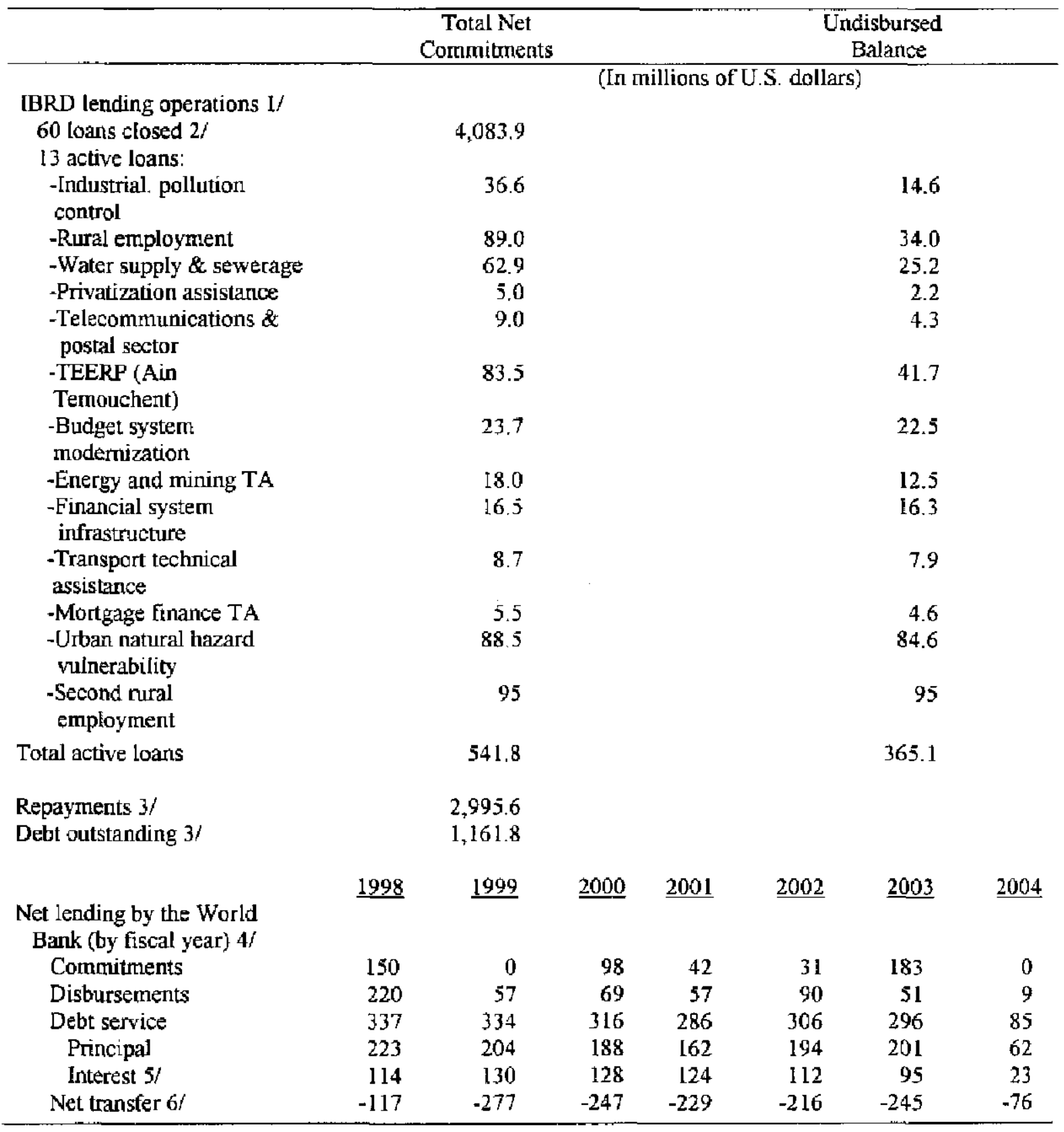

I/ IDA has no operations in Algeria.

2/ Less cancellations, includes adjustment lending.

3/ As of September 30, 2003.

4/ Fiscal years start July 1 and end June 30.

$5 /$ Includes charges.

6/ Equal to disbursernents minus debt service. 


\section{Algeria: Statistical Issues}

Following the expiration of the extended arrangement in May 1998, the reporting of statistics to the Fund generally deteriorated, particularly with respect to the quality and timeliness of data forwarded between missions. The lack of financial resources allocated to the compilation of statistics, insufficient inter agency coordination, as well as concerns about accuracy and subsequent reluctance to publish provisional data, are partly responsible for this situation. If this trend is not reversed soon and the quality and timeliness of economic data rapidly improved, deterioration may reach a point where it could prevent adequate surveillance.

\section{Real sector}

Real sector data is being reported to STA on an irregular basis with substantial lags. The latest national accounts information in IFS pertains to partial data reported for 2000. IFS import trade data at current prices are derived from Direction of Trade Statistics. The September 2002 multisector statistics mission recommended that priority be given to move the compilation of national accounts to 1993 SNA.

\section{Government finance}

Algeria reported government finance statistics (GFS) for the period 1994-2002 for publication in the GFS yearbook. However, the institutional coverage of the data reported is limited to Budgetary Central Government, albeit in a wide sense, including the general budget, the annexed budget, and the special treasury accounts. Clarification has been sought from the authorities regarding the important question of the basis of recording of the latter (net versus gross recording). No sub-annual data are submitted for IFS publication. The September 2002 multisector statistics mission recommended the designation of a coordinator and the assignment of at least one economist for the compilation of GFS. The authorities have not yet followed up on their initial intention to assign GFS leadership to the Ministry's General Directorate of Accounting. A first task would be the establishment of an automated bridge table between the detailed monthly Treasury ledger (Balance générale), regularly produced by the latter, and the GFS table (Situation résumée des Opérations du Trésor -SROT) in order to ensure a more timely production of quarterly and monthly GFS, as well as a more timely report to the Fund of annual and quarterly data. The on-going changeover to an enhanced chart of accounts of the Treasury would be an ideal occasion to revamp the way GFS compilation is organized and carried out in Algeria.

The mission recommended further (a) that proceeds of the oil stabilization fund (FRR) be shown as revenue (rather than financing); (b) the compilation of further breakdowns in particular relating to the item "other transfers"; (c) a more appropriate reporting of the three large debt assumptions operations carried over the past decade; and (d) further work on the financing and the reconciliation with monetary statistics. The mission noted that meeting the GDDS and eventually the SDDS standards would require substantial efforts in terms of 
extension of coverage (consolidating the operations of social security and Wilayate, and subsequently of other administrative bodies and municipalities)

\section{Monetary accounts}

Monetary data is broadly adequate for policy formulation and monitoring of economic developments. In particular, coverage has improved with the consolidation of data from the national savings bank (CNEP). However, reporting of balance sheet data by some commercial banks is very untimely, and most commercial banks do not report complete data that is needed to compile the monetary survey. The September 2002 STA multisector statistics mission recommended expanding further the coverage of the monetary survey to include banking operations of the National Mutual Fund for Agriculture (CNMA) and strictly enforcing the reporting obligations of banks by introducing high penalties.

\section{Balance of payments}

A balance of payments statistics mission visited Algeria in 1993. The September 2002 multisector statistics mission noted the following: (i) the Bank of Algeria 's legal authority to collect data is limited to banking and financial institutions only; (ii) data sources need to be expanded by conducting enterprise survey in addition to traditional exchange-based records; (iii) a more rigorous and uniform application of the residency criterion should be followed; (iv) quarterly data are compiled but not regularly disseminated; and (v) international investment position data are not compiled. 
Algeria: Core Statistical Indicators

(As of November 13, 2003)

\begin{tabular}{|c|c|c|c|c|c|c|c|c|c|c|}
\hline & $\begin{array}{l}\text { Exchange } \\
\text { rate }\end{array}$ & $\begin{array}{l}\text { International } \\
\text { Reserves }\end{array}$ & $\begin{array}{l}\text { Broad } \\
\text { Money }\end{array}$ & $\begin{array}{l}\text { Interest } \\
\text { Rates }\end{array}$ & $\begin{array}{l}\text { Consumer } \\
\text { Price Index }\end{array}$ & $\begin{array}{l}\text { Exports/ } \\
\text { lmports }\end{array}$ & $\begin{array}{l}\text { Current } \\
\text { Account } \\
\text { Balance }\end{array}$ & $\begin{array}{l}\text { Overall } \\
\text { Goverument } \\
\text { Balance }\end{array}$ & GDP/GNP & $\begin{array}{c}\text { External } \\
\text { Debt and } \\
\text { Debt } \\
\text { Service }\end{array}$ \\
\hline Date of latest observation & $09 / 30 / 03$ & $09 / 30 / 03$ & $08 / 30 / 03$ & $10 / 30 / 03$ & $09 / 30 / 03$ & $06 / 30 / 03$ & $06 / 30 / 03$ & $06 / 30 / 03$ & $12 / 31 / 02$ & $12 / 31 / 02$ \\
\hline Date received & $10 / 09 / 03$ & $10 / 09 / 02$ & $11 / 13 / 03$ & $11 / 13 / 03$ & $10 / 20 / 03$ & $10 / 02 / 03$ & $10 / 02 / 03$ & $10 / 06 / 03$ & $06 / 20 / 03$ & $02 / 16 / 03$ \\
\hline Frequency of data $U /$ & M & M & $\mathbf{M}$ & $\mathrm{M}$ & M & $Q$ & $Q$ & $Q$ & A & A \\
\hline $\begin{array}{l}\text { Frequency of } \\
\text { Reporting } 1 /\end{array}$ & $\mathrm{M}$ & $M$ & $v$ & $M$ & $\mathrm{M}$ & $\mathrm{V}$ & $\mathrm{V}$ & V & $v$ & V \\
\hline Source of data $2 /$ & A & A & A & A & N & A & A & A & A & $A$ \\
\hline Mode of reporting $3 /$ & $\mathrm{C}$ & $\mathrm{c}$ & $\mathrm{E}$ & E & I & $\mathrm{v}$ & $v$ & $\mathrm{~V}$ & $\mathrm{v}$ & $\mathrm{C}$ \\
\hline Confidentiality $4 /$ & $\mathrm{C}$ & c & $\mathrm{C}$ & $\mathrm{C}$ & $\mathrm{c}$ & $\mathrm{c}$ & $\mathrm{C}$ & $\mathrm{C}$ & $\mathrm{c}$ & $\mathrm{C}$ \\
\hline $\begin{array}{l}\text { Frequency of publication } \\
\text { 1/ }\end{array}$ & $\mathbf{M}$ & $\mathbf{M}$ & $\mathbf{M}$ & $\mathbf{M}$ & $\mathrm{M}$ & A & A & $Q$ & A & A \\
\hline
\end{tabular}

1/ D-daily, W-Weekdy, M-motthly; Q-quarterly; A-atmually; V-irregularly in conjunction with staff visits.

2/A-direct reporting by central bank, ministry of finance, or other official agency; $\mathrm{N}$-official publication or press release; $\mathrm{P}$-commercial publication, C-commercial electronic data provider, Ë-EIS.

3/ E-electronic data transfer; C-cable or fassimile; I-Intenet website; T-telephone; M-mail; V-statf visits.

$4 /$ C-for unrestricted use. 
Algeria: Social Indicators

\begin{tabular}{|c|c|c|c|c|c|}
\hline & 1997 & 1998 & 1999 & 2000 & 2001 \\
\hline \multicolumn{6}{|l|}{ Population } \\
\hline Resident population (in millions) & 29.0 & 29.5 & 30.0 & 30.4 & 30.8 \\
\hline Population aged 0-14 (in millions) & 10.9 & 10.9 & 10.9 & 11.0 & 10.9 \\
\hline Rural population (percent of total) & 44.6 & 44.0 & 43.4 & 42.9 & 42.3 \\
\hline Birth rate (per thousand) & 26.5 & $\ldots$ & 25.3 & 23.7 & 22.7 \\
\hline Death rate (per thousand) & 6.1 & $\ldots$ & 5.6 & 5.4 & 5.2 \\
\hline Growth rate (in percent) & 1.6 & 1.5 & 1.4 & 1.5 & 1.6 \\
\hline \multicolumn{6}{|l|}{ Health } \\
\hline Infant mortality (per thousand) & 40.0 & & 34.0 & 40.0 & 39.0 \\
\hline Physicians (per thousand people) & $\ldots$ & 1.0 & 0.8 & $\ldots$ & $\ldots$ \\
\hline \multicolumn{6}{|l|}{ Education } \\
\hline Primary School errollment (percent net) $1 /$ & $\ldots$ & 96.8 & 97.2 & 98.3 & 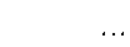 \\
\hline Secondary School enrollment (percent net) $/ /$ & $\ldots$ & 58.9 & 58.5 & 61.8 & \\
\hline Illiteracy rate $2 /$ & 37.1 & 35.8 & 34.5 & 33.3 & 32.2 \\
\hline \multicolumn{6}{|l|}{ Ëmployment } \\
\hline Labor force (percent of total population) & 32.0 & 32.5 & 33.1 & 33.7 & 34.3 \\
\hline Unemployment (percent of labor force) & 28.7 & $\ldots$ & $\ldots$ & 29.8 & $\ldots$ \\
\hline \multicolumn{6}{|l|}{ Income } \\
\hline GDP per capita in U.S. dollars 3/ & $1,513.3$ & $1,565.6$ & $1,591.8$ & $1,606.7$ & $1,616.5$ \\
\hline
\end{tabular}

Source: World Development Indicators (World Bank, 2002)

l/ Percentage of age group over same age group enrolled in education. $2 /$ In percent of population aged 15 and above.

$3 /$ Constant 1995 U.S. dollar. 


\section{Statement by the IMF Staff Representative \\ January 14, 2004}

The following information has become available since the issuance of the staff report for the 2003 Article IV consultation with Algeria. This additional information does not change the thrust of the staff appraisal:

- Gross foreign exchange reserves increased to $\$ 32.9$ billion at end-December 2003 (23.6 months of the projected imports of goods and services). The difference with the amount projected in the staff report ( $\$ 31.5$ billion) is mainly due to the valuation effect arising from the appreciation of the euro at the end of 2003.

- The 12-month average inflation rate (as measured by the consumer price index) was 2.1 percent at end-November 2003. Staff projection for 2003 is 2.3 percent.

The DA/US dollar exchange rate closed at 72.6 at end-December 2003 (against 79.7 at end-December 2002). The DA/euro exchange rate reached 91.3 at end-December 2003 (from 83.5 at end-December 2002).

- Treasury deposits at the Bank of Algeria rose to DA 602 billion at end-December 2003 (11.8 percent of the projected 2003 GDP) from DA 430.6 billion at endDecember 2002 (9.7 percent of the 2002 GDP). The staff projection in SM/03/397 is DA 600 billion.

- A third cellular telephone license has been issued to Kuwait National MobilesTelecommunications, known as Wataniya, which offered the highest bid (\$421 million).

- 19 small enterprises have been privatized in the latter part of the year. These transactions have been either completed or are in the process of being finalized after an agreement has been found with investors. They are distributed as follows: 1 hotel, 7 brickyards, 1 cement factory, and 10 other small enterprises transferred to employees. 


\section{INTERNATIONAL MONETARY FUND}

Public Information Notice

Public Information Notice (PIN) No. 04/3

EMBARGOED

NOT FOR NEWSWIRE TRANSMISSION

UNTIL 4:00 PM WASHINGTON TIME (2100 GMT)

January 29, 2004
International Monetary Fund $70019^{\text {th }}$ Street, NW

Washington, D. C. 20431 USA

\section{IMF Concludes 2003 Article IV Consultation with Algeria}

On January 14, 2004, the Executive Board of the International Monetary Fund (IMF) concluded the Article IV consultation with Algeria. ${ }^{1}$

\section{Background}

Despite volatile oil markets and a difficult political and social environment, Algeria has maintained macroeconomic stability since the successful completion of its Fund-supported adjustment and reform programs in 1998. GDP growth has strongly recovered from its slowdown in 2000, inflation has been generally maintained at industrial-country level and the external position has strengthened significantly.

In the context of weak economic growth and the accumulation of large treasury deposits at the central bank owing to rising hydrocarbon revenues since mid-1999, the government has eased the fiscal stance since 2001 with a view to fostering economic growth and generating employment. Additional fiscal impetus was generated by the increase in expenditure to finance the reconstruction needs following the devastating May 2003 earthquake.

\footnotetext{
' Under Article IV of the IMF's Articles of Agreement, the IMF holds bilateral discussions with members, usually every year. A staff team visits the country, collects economic and financial information, and discusses with officials the country's economic developments and policies. On return to headquarters, the staff prepares a report, which forms the basis for discussion by the Executive Board. At the conclusion of the discussion, the Managing Director, as Chairman of the Board, summarizes the views of Executive Directors, and this summary is transmitted to the country's authorities.
} 
The overall budget surplus declined in 2001 and 2002, before strengthening again in the course of 2003 as a result of thriving hydrocarbon revenues. The overall budget is expected to record an end-year surplus of over 3 percent of GDP, after a near balance in 2002. At the same time, the primary nonhydrocarbon deficit would surpass 32 percent of nonhydrocarbon GDP in 2003, after an already elevated 28.7 percent in the preceding year.

Monetary developments were characterized by a significant increase in liquidity sternming from the substantial increase in net foreign assets and expansion of credit to the economy. The money supply $M 2$ is expected to continue to increase substantially in 2003 , despite measures to mop up some of the excess liquidity in the banking system. The banking sector was adversely affected by the fraudulent bankruptcy of the two largest (yet small) private banks.

Throughout 2002 and the first half of 2003, the external position of Algeria continued to strengthen. The 2003 current account surplus will rise sharply owing to booming hydrocarbon exports. Official reserves already increased to US\$30.4 billion (22 months of imports) as of endOctober 2003, surpassing gross external debt since end-2002.

After expanding at a rate of 4.1 percent in 2002, real GDP growth is expected to further pick up in 2003 to about 6.7 percent. While growth in 2002 was limited by weak agricultural production as a result of adverse weather conditions, it was boosted by an exceptional harvest and a strong hydrocarbon sector performance in 2003. Against this background, the high unemployment rate (estimated at 25.9 percent of the labor force in 2002-the latest available data) is projected to drop. Low food prices and gradual tariff reductions have led to low inflation (1.4 percent in 2002 and a projected 2.3 percent in 2003), despite abundant domestic liquidity and booming credit.

While the overall pace of structural reform remained slow, some progress has been achieved in trade liberalization and the development of treasury securities markets. In light of the difficulties in completing a number of large privatization projects, the authorities have recently developed a pragmatic attitude towards privatization, considering both full and partial sales of public enterprises as well as joint ventures with private investors.

\section{Executlve Board Assessment}

Executive Directors welcomed the strengthening of Algeria's economic performance over 2002 and 2003, with high economic growth, low inflation, a marked strengthening of the balance of payments, and an accumulation of international official reserves. These achievements are largely attributable to a combination of strong agriculture performance, boosted by favorable weather conditions, continued high oil prices, and supportive fiscal policies. Progress has also continued to be made in some structural areas, including trade liberalization and the development of treasury securities markets.

While growth prospects remain favorable in the period immediately ahead, Directors underscored that the Algerian economy continues to face serious challenges. Despite some decline recently, unemployment remains high, and the rise in living standards is still slow. To 
achieve sustained, job-creating growth, Directors agreed that Algeria will need to reinvigorate structural and institutional reforms aimed at significantly increasing the role of the private sector in the economy.

Directors acknowledged the role that supportive fiscal policies have played in boosting growth and employment creation in the face of weak private sector activity, and in coping with the reconstruction needs following the May 2003 earthquake. They noted that Aigeria's pressing social and infrastructure needs will continue to call for high levels of investment in the coming years. While not a substitute for structural reforms, public investment will continue to have to play a role in meeting these needs and strengthening the foundation for sustained growth. At the same time, however, Directors cautioned that the high level of public spending-currently made possible by high oil prices-also entails risks. It heightens the vuinerability of public finances in the face of the uncertainty and volatility of oil prices and, by contributing to large liquidity swings, risks complicating both the conduct of monetary policy and commercial bank management. A continued rapid rise in capital spending would also risk weakening the quality and effectiveness of public investment.

To ensure the long-term sustainability of the public finances, Directors urged the authorities to gradually tighten the fiscal stance, while managing public expenditure in a way that reduces vulnerability to developments in the oil market. Stabilizing public expenditures as a percentage of nonhydrocarbon GDP at a sustainable level could be a useful guide for the longer term. At the same time, Directors considered that improved prioritization of public investment based on efficiency considerations will allow public investment to play a complementary role in supporting structural reform efforts. To improve fiscal transparency and public expenditure management, they encouraged the authorities to record in the budget the quasi-fiscal activities generated by public bank losses. The forthcoming fiscal Report on the Observance of Standards and Codes will provide a welcome opportunity to discuss the scope for further strengthening fiscal management in the period ahead.

Directors welcomed the authorities' resolve to devote monetary policy to preserving Algeria's low inflation record. They cautioned that this will require heightened vigilance in the period ahead, as the recent rapid growth of money and credit could increase inflationary pressures and credit risk. Directors encouraged the central bank to further develop its monetary policy instruments, and fully absorb bank excess liquidity. To facilitate liquidity management, they also saw scope for greater coordination between the central bank and the ministry of finance in the issuance of Treasury securities.

Directors observed that Algeria's managed float exchange rate regime has continued to serve the country well. They endorsed the authorities' decision to refrain from targeting a further real effective appreciation of the dinar, as this could hamper the development of the private sector and the diversification of the narrow export base. Going forward, Directors welcomed the Bank of Algeria's commitment to continue to implement the managed float in a flexible manner, with further gradual liberalization of the exchange system fostering a greater role of market forces in determining the exchange rate. 
Directors urged the authorities to take advantage of Algeria's current favorable macroeconomic situation to accelerate implementation of the country's wide-ranging structural reform agenda. In particular, it will be important to mobilize strong public support for well-sequenced actions that improve the climate for a durable and diversified expansion of private-sector-led growth and investment. Among the high priorities, in this regard, will be a comprehensive reform of the financial sector and public enterprise restructuring and privatization. Directors highlighted the importance of accompanying the reforms with an adequate social safety net to cushion their possible adverse short-term impact. Further steps to improve governance and strengthen the institutional underpinnings of a market economy, to address land tenure issues, and to institute active labor market policies should also be high on the agenda. Some Directors expressed concern about the impact on employment opportunities of the recent increase in the minimum wage.

Directors welcomed the authorities' commitment to financial sector reform, and looked forward to the early adoption of a plan for the implementation of the Financial Sector Stability Assessment recommendations. They urged the authorities to replace bank loans to loss-making enterprises with temporary budget subsidies in the context of a medium-term restructuring program. Directors also stressed the need to modernize the payments system, and to enhance the efficiency and profitability of public banks. This should be helpful as the authorities consider a progressively greater role for the private sector in the banking system. The recent failure of two private banks underscores the need to strengthen prudential regulations and bank supervision. In this context, Directors. welcomed the recent measures to strengthen bank licensing and improve the supervisory framework, and encouraged the authorities to maintain and strengthen the independence of the central bank and the banking commission.

Directors commended the authorities for achieving significant progress in trade liberalization and for their commitment to trade policy reforms ahead of joining the World Trade Organization. They encouraged the authorities to press ahead with the adoption of anti-money laundering legislation.

Directors welcomed the authorities' initiative to engage in more active debt management, and their intention to request a sovereign credit rating, which will facilitate Algeria's retum to the international capital markets. They encouraged the authorities to include collective action clauses in future foreign bond issuances. Directors welcomed the authorities' intention to continue to cooperate with the Russian authorities toward an expeditious settlement of bilateral debt issues. While welcoming the authorities' decision to grant debt relief on a case by case basis to HIPC eligible countries, Directors encouraged the authorities to become full participants in the enhanced HIPC Initiative. Given Algeria's current strong external position, it was also suggested that the authorities consider making voluntary early repurchases of their outstanding financial obligations to the Fund.

Directors looked forward to further efforts by the authorities to address Algeria's statistical weaknesses. They commended the authorities' intention to participate in the Fund's Special Data Dissemination Standard (SDDS), which will require significant steps to improve the quality and timely publication of data. 
Public Information Notices (PINs) are issued, (i) at the request of a member country, following the conclusion of the Article IV consultation for countries seeking to make known the views of the IMF to the public. This action is intended to strengthen IMF surveillance over the economic policies of member countries by increasing the transparency of the IMF's assessment of these policies; and (ii) following policy discussions in the Executive Board at the decision of the Board.

Algeria: Selected Economic Indicators

\begin{tabular}{|c|c|c|c|c|c|c|}
\hline & 1998 & 1999 & 2000 & 2001 & 2002 & 2003 \\
\hline & \multicolumn{6}{|c|}{ (In percent) } \\
\hline \multicolumn{7}{|l|}{ Domestic economy } \\
\hline Real GDF & 5.1 & 3.2 & 2.2 & 2.6 & 4.1 & 6.7 \\
\hline GDP defliator & -3.1 & 11.2 & 23.5 & 0.8 & 0.9 & 7.4 \\
\hline Consumer price index (average) & 5.0 & 2.6 & 0.3 & 4.2 & 1.4 & 2.3 \\
\hline & \multicolumn{6}{|c|}{ (In billions of U.S. dollars) . 1/ } \\
\hline External sector & & & & & & \\
\hline Exports, f.o.b. & 10.1 & 12.3 & 21.7 & 19.1 & 18.7 & 24.3 \\
\hline Imports, f.o.b. & 8.6 & 9.0 & 9.3 & 9.5 & 12.0 & 13.3 \\
\hline Current account (in percent of GDP) & -1.9 & 0.0 & 16.8 & 12.9 & 7.8 & 11.5 \\
\hline Capital account balance & -0.8 & -2.4 & -1.6 & -0.9 & -0.7 & -0.7 \\
\hline Gross official reserves & 6.8 & 4.4 & 11.9 & 18.0 & 23.1 & 31.5 \\
\hline External debt (in percent of GDP) & 64.3 & 58.6 & 46.6 & 41.3 & 40.5 & 32.7 \\
\hline Debt service ratio (in percent of exports) & 46.3 & 40.3 & 20.3 & 22.8 & 22.6 & 17.1 \\
\hline \multirow[t]{2}{*}{ Real effective exchange rate $2 /$} & 4.8 & -7.9 & -2.5 & 2.8 & -7.8 & $\cdots$ \\
\hline & \multicolumn{6}{|c|}{ (In percent of GDP) 1 / } \\
\hline \multicolumn{7}{|l|}{ FInanclal variables } \\
\hline Overall budget balance (deficit-) & -3.8 & -2.0 & 9.7 & 3.4 & 0.2 & 3.5 \\
\hline Change in broad money (M2) (in percent) & 47.2 & 12.4 & 13.2 & 22.2 & 17.4 & 16.0 \\
\hline Interest rale (central bank rediscount rate, in percent) & 9.5 & 8.5 & 6.0 & 6.0 & 5.5 & 4.5 \\
\hline
\end{tabular}

Sources: Data provided by the Algerian authorities; and IMF staff estimates.

1/ Unless otherwise noted.

2/ A decrease in the index implies a depreciation. 


\section{Statement by Abbas Mirakhor, Executive Director for Algeria January 14, 2004}

My Algerian authorities thank staff for their focused report and useful Selected Issues paper. They are grateful to the Executive Board, management, and staff for the quality of the dialogue, the constructive advice, and the continued support. They highly valued the recent visit of the group of Executive Directors to Algeria, which was an opportunity to deepen mutual understanding. The authorities also thank Fund and World Bank staffs for their hard work and valuable recommendations in the context of the recent FSAP missions.

\section{Recent economic developments}

\section{A. Economic activity and inflation:}

Economic activity continued to improve in 2002 and 2003. Growth was strong, with real GDP further picking up from 4.1 percent in 2002 to 6.8 percent in 2003 -the highest rate over the past two decades - reflecting strong performance in the agriculture, hycrocarbon, construction, and non-government services sectors. Excluding hydrocarbons, GDP growth reached 4.2 percent in 2002 , and 6.0 percent in 2003 . As a result, unemployment, though still high, has declined. Inflation remained subdued, mainly on account of low food prices and gradual reduction in the external tariff. The external position continued to strengthen, underpinned by higher hydrocarbon exports. The current account surplus rose from 7.8 percent of GDP in 2002 to 11.5 percent of GDP in 2003 , and official reserves reached $\$ 32.9$ billion by end-December 2003 , representing two years of imports of goods and nonfactor services, and significantly exceeding total external debt.

\section{B. Fiscal performance and policy:}

Fiscal policy in 2002 and 2003 reflected the authorities 'determination to stimulate growth in view of the still insufficient contribution of the private sector to growth-oriented economic activity, while maintaining a sustainable fiscal position. Additional fiscal expenditure has focused on promoting labor-intensive activities, construction, local development projects, and rehabilitation and development of infrastructure to foster growth, employment, and private-sector development. At the same time, the authorities, with World Bank assistance, have paid due attention to expenditure efficiency by cutting non-priority outlays, while preserving social spending, notably in education, health, and housing. However, additional expenditure pressures arose following the May 2003 devastating earthquake, which led to losses of 2500 lives and damages estimated at $\$ 5$ billion. Consequently, a supplemental Budget Law provided for earthquake-related appropriations in 2003, and additional funding was provided in the 2004 Budget Law. Despite these pressures, the overall fiscal balance has recorded an estimated surplus close to 4 percent of GDP in 2003, up from near balance in 2002 , as a result of higher revenues, tight current spending, and rationalized capital expenditure. As part of their prudent approach to fiscal management, the authorities 
continued to build up sizable deposits at the central bank, which increased to 600 billion dinars by end-December 2003 (11.7 percent of GDP) from 430 billion dinars by end-2002 (9.7 percent of GDP).

\section{Monetary developments and policy:}

The continued increase in net external assets in 2002 and 2003, which represented the major source of monetary creation, resulted in significant monetary expansion, as measured by the increase in M2. However, this did not translate into higher inflation. As reflected in the Selected Issues paper, real factors have played a role in dampening inflation. Moreover, a significant part of the hydrocarbon revenues was sterilized in the form of increased Treasury deposits at the central bank. The central bank also regularly intervened to mop up excess liquidity in the banking system. To this end, it increased reserve requirements from 4.25 percent to 6.25 percent, as well as the amounts of central bank deposit auctions. As recommended by staff, the central bank is committed to further strengthening the latter instrument to contain inflation pressures. It also welcomes staff advice on relinquishing its role as broker on the interbank market, and is moving in this direction. As staff noted, credit to the economy has increased substantially, with a significant part directed to the private sector. The authorities note staff concerns regarding its possible impact on inflation and bank soundness, and witl address these risks through increased liquidity absorption, enhanced supervision, and strengthened monitoring of banks' credit provisioning, in line with FSAP recommendations.

The exchange rate continued to be managed flexibly, with the objective of maintaining real effective exchange rate (REER) stability. As staff noted, the central bank intervened during the second half of 2003 to correct an initial depreciation during the first half of the year resulting from the low inflation rate and the continued depreciation of the dollar against the euro. As indicated in the staff report, by end-2003 the REER returned to its level at end-2002 and was 8 percent below the level of end-2001. The authorities do not target further effective real appreciation of the dinar and remain committed to their present exchange rate policy, paying particular attention to avoiding substantial misalignment of the REER. They thank staff for their recommendations on further liberalizing the exchange system and will proceed gradually with their implementation.

\section{Progress with structural reforms:}

Progress continue to be achieved in trade liberalization, with modernization of the legislative framework following issuance of new ordinances addressing issues on international trade, organization of free trade zones, protection of intellectual rights, and competition in line with World Trade Organization (WTO) rules. In addition, implementation of the tariff reform has contimued as scheduled, with the temporary additional duty progressively reduced to 36 percent as of January 1, 2003, and to 24 percent as of January 1, 2004, to be eliminated totally by January 2006. Discussions on Algeria's WTO accession are well advanced, while the Association Agreement with the European Union should be ratified by the European partners in the course of 2004. 
Important strides have been taken in the public enterprises restructuring/privatization process. The authorities have adopted a pragmatic approach consisting of privatizing any public enterprise ready for privatization and for which there is a reasonable interest from private local or foreign investors. Concurrently, the authorities are continuing to restructure the remaining enterprises to enhance their attractiveness. Moreover, public enterprises are encouraged to seek private partnership through joint-ventures, and foreign direct investment is further facilitated through more expeditious and streamlined, yet transparent procedures. In this context, the Council of State Participations (CPE) has approved, over the last six months, 19 privatization operations, including seven brickyards. The privatization process of three cement factories has been re-launched, building on the lessons of the earlier unsuccessful attempt, and discussions are being held with 10 international bidders. New bids are also being envisaged for the transfer of the management of the airport to the private sector. The privatization of the major beverage group is also at an advanced stage. In addition, the telecommunication sector was further opened to the private sector through the recent sale, for an amount of \$421 million, of a third GSM license to a foreign investor. Along with privatization and restructuring actions, seven joint-ventures have been recently created in different sectors, including the pharmaceutical, textile and leather, water management, electronics, and construction materials sectors.

In the banking sector, efforts are still ongoing to privatize one public bank and measures are taken to increase the market share of quality private banks, while improving the sector's operating framework, in line with FSAP recommendations. Modernization of the payment system is given high priority and is being closely monitored by an inter-ministerial council, chaired by the head of the government. Bids for modemization of the real time gross settlements component are being examined at the Bank of Algeria, under a World Bankfinanced project, while the modernization of the small payments component is under preparation.

Following the recent fraudulent bankruptcy of two small private banks, the authorities have focused on improving the quality of potential new entrants in the banking sector. In this context, a new ordinance on money and credit has been issued, tightening bank licensing requirements. Supervision has been significantly enhanced over the past years, and further strengthening is proceeding with Fund assistance. The authorities agree with staff on the need to replace bank credit to loss-making public enterprises with explicit budget subsidies. Initial measures have been taken in the 2004 Budget Law involving, in particular, the national airline company. The authorities are committed to further significant progress in this area, within a comprehensive restructuring program.

As staff noted, the authorities share the thrust of FSAP conclusions and are working toward early adoption of an action plan to implement the recommendations, including further strengthening the AML/CFT framework. Regarding the FSAP recommendation to privatize all public banks in the medium term, the authorities consider that soundness and efficiency, not ownership, should be the overriding criteria. While they agree that a greater role of private banks would be more consistent with a market economy, they believe that a more prudent and gradual approach in privatization is warranted and are moving in this direction. 


\section{Medium-term policy issues}

The authorities are committed to maintaining a stable macroeconomic environment, and to move ahead with the remaining agenda of reforms. However, they attach high importance to appropriate sequencing and phasing of the reforms, commensurate with the country's political and social circumstances and to mobilizing strong public support for the reform process.

As noted above, the authorities consider fiscal stimulus a necessary supportive policy at this particular juncture for promoting growth and employment. However, they believe that it cannot be a substitute for further reforms to create an enabling environment for private sector development, and that it cannot be sustainable, given the volatility of hydrocarbon revenues. They are committed to continue containing current expenditure and rationalizing capital expenditure, while providing the necessary appropriations for reconstruction and rehabilitation of infrastructure damaged by terrorism and natural disasters, including schools, hospitals, roads, and railroads. They attach high priority to enhancing non-hydrocarbon revenues, and have recently requested Fund technical assistance in tax administration, including for the efficient functioning of the large tax payers unit. Meanwhile, the authorities remain committed to promoting private participation in economic activity, through improved infrastructure, better governance, strengthened institutions, while pressing ahead with public enterprise restructuring and privatization as well as financial sector reform in line with FSAP recommendations.

The authorities thank staff from the International Capital Markets (ICM) for their technical assistance and policy advice on assets/liabilities management, sovereign rating, and return to international capital markets. They intend to gradually implement ICM recommendations, including buying back part of the external debt, and they count on continued Fund technical support in this area.

As part of their continued commitment to transparency, the authorities have agreed to the publication of the staff report, the Selected Issues document, and the FSSA report. 